\title{
Cassatie in civiele zaken (Belgisch recht)
}

Ivan Verougstraete*

\section{Inleiding}

I. Het Hof van Cassatie van België en de Hoge Raad der Nederlanden bestaan ongeveer even lang: het Hof van Cassatie is net 175 jaar oud, de Hoge Raad werd zes jaar na het Hof van Cassatie geïnstalleerd. Beide zijn opgericht naar het Frans model, maar wel van bij het begin met een uiteenlopende structuur: de Belgische instelling sloot veel nauwer aan bij de Franse dan de Nederlandse. ${ }^{\mathrm{I}}$

Maar voor de ene en de andere geldt dat zij de top vormen van de rechterlijke hiërarchie en geen instantie naast zich hebben en door geen instantie gecontroleerd worden. Zoals de Grondwet het in quasi-magische termen uitdrukt: 'er is voor geheel België een Hof van Cassatie'. Die regel is symbolisch en materieel geladen in een land dat de laatste eeuwen af en toe wat interne spanningen kende.

De redeneertrant van het Hof weerspiegelt die uniciteit: het Hof verantwoordt niet waarom het de ene of de andere weg kiest. ${ }^{2}$ In het jaarverslag van het Hof komt er weliswaar een toelichting bestemd voor een breder publiek waarin de opvattingen van het Hof en de situering van de rechtspraak worden gedaan. ${ }^{3}$ Het is slechts zeer onlangs dat het Hof expliciet in een arrest zegt dat het omgaat en een nieuwe weg opgaat. 4

2. De evolutie van de politieke instellingen van het land beïnvloedt de werking en de taken van het Hof van Cassatie. In het verleden stond aan de top van de juridische piramide het Hof van Cassatie, met niemand naast zich en bekleed met de eerbiedwaardigheid eigen aan de aard en de opdracht van dit rechtscollege. Zoals in een sterk hiërarchische maatschappij hoort, werden de beslissingen aan de top genomen en daalden die beslissingen neer via de geëigende wegen naar de ondergeschikten die ze al dan niet loyaal uitvoerden. ${ }^{5}$

De piramidale structuur gaat ervan uit dat de top geen instantie naast zich heeft noch gecontroleerd wordt. Welnu, het Hof van Cassatie heeft naast zich een aantal

* Voorzitter van het Hof van Cassatie.

I. Zie hierover W.E. Haak, 'De evolutie op lange termijn van de Nederlandse cassatieprocedure in burgerlijke zaken sedert I838', in: 175 jaar Hof van Cassatie, Larcier 2007 (in druk); HR I8 maart I953, NJ I953, 36r, noot Veegens.

2. Zie hierover R. De Corte, 'De eerste honderd vijf en zeventig jaar van het Hof van Cassatie', in: 175 jaar Hof van Cassatie, Larcier 2007 (in druk); zie ook F. Dumon, De opdrachten van de hoven en rechtbanken. Enkele overwegingen', R.W.1975-76, I94 en 257.

3. Het Hof gebruikte vaak die omweg om aan te wijzen wanneer het omgaat: zie bijv. Cass.20 juni 2005, met commentaar in het jaarverslag p. 27.

4. Cass.24 juli 2007, www.cass.be.

5. R. De Corte, op. cit., in druk. 
organen gekregen die zijn positie minder duidelijk maken en die de hiërarchische structuur van de rechterlijke macht grondig hebben aangetast.

In 1946 is de Raad van State opgericht die een hoogste administratief rechtscollege werd en maar in beperkte mate onderworpen is aan het toezicht van het Hof van Cassatie (voor de regeling van attributieconflicten).

Van groter belang nog was de oprichting van een Grondwettelijk Hof bevoegd voor de toetsing van wetten en decreten aan de Grondwet ${ }^{6}$ en dat buiten de rechterlijke macht staat. De toekenning van zeer grote bevoegdheden aan het Grondwettelijk Hof leidt tot een verschuiving van de macht en zou kunnen ontaarden in een 'dicastocratie' zoals B.Bouckaert het terecht stelt, wanneer het Grondwettelijk hof de Grondwet als een uiterst rekbaar gegeven zou hanteren en een soort wetgeverplaatsvervanger worden. ${ }^{7}$ Zowel de rechterlijke macht (en het Hof van Cassatie in het bijzonder) als de wetgevende macht staan onder een beperkte voogdij van het Grondwettelijk Hof.

Ten slotte hebben internationale gerechten zoals het Benelux-gerechtshof, het Hof van Justitie van de Europese Gemeenschappen (hierna: Hof van Justitie) en het Europees Hof voor de Rechten van de Mens (hierna: EHRM) ook een deel bevoegdheid gekregen om te oordelen over conflicten van subjectieve en objectieve aard zodat er van eenduidigheid in de rechtshandhaving geen sprake meer is. Een voor de gemiddelde jurist weinig overzichtelijk netwerk heeft de vroegere pyramidale structuur vervangen.

Die nieuwe structuur - waarin het Hof van Cassatie maar een deel is van een netwerk - heeft het Hof van Cassatie verplicht zijn gezag meer expliciet te verantwoorden. Zoals R.De Corte het terecht stelt, moet het Hof van Cassatie arresten wijzen die beantwoorden aan integrale kwaliteitseisen, zowel in werkelijkheid als in de perceptie van de maatschappij. ${ }^{8}$

3. De creatie van nieuwe instellingen en de evolutie van de maatschappij leiden niet altijd op korte termijn tot een wijziging en aanpassing van de bestaande instellingen die getroffen worden door de evolutie. Er is altijd een zekere tijd nodig om de wijzigingen te integreren en zolang dat niet gebeurt, is er op het eerste gezicht niet zoveel veranderd in het juridische landschap. De wijzigingen in de instellingen hebben nochtans op middellange termijn een invloed gehad op het Hof van Cassatie zoals hierna wordt gedemonstreerd.

De federalisering van België gevolgd door een verdere defederalisering (of halve confederalisering) van het land, en de onafgewerkte Europese integratie zijn niet volledig aan het Hof voorbijgegaan. Maar heel wat gevolgen van die wijzigingen moeten nog worden geïntegreerd, zowel in de structuren als in de rechtspraak.

Het Hof van Cassatie zal nog verder evolueren: de eerste sporen van een belangrijke kentering zijn nu al te zien. Ook is nu al zichtbaar welke de harde kern zal zijn

6. Voor een beschrijving van de relaties tussen de drie instellingen zie A. Arts, I. Verougstraete, R. Andersen, G. Suetens-Bourgeois, M.F. Rigaux, R. Ryckeboer, A. De Wolf (eds.), De verhouding tussen het Arbitragehof, de Rechterlijke Macht en de Raad van State, Brugge, Die Keure, 2006, 394 p.

7. B. Bouckaert, 'Hoe gemotiveerd is cassatie?', Thorbecke colleges I997, p.5, Story Scientia 1997.

8. R. De Corte, 'De eerste 175 jaar van het Hof van Cassatie', cit. Larcier 2007, in druk. 
waarin het Hof van Cassatie de essentie van zijn taak ziet en waaraan het niet wil dat er zou getornd worden. Het motto is dat een wijziging alleen kan wanneer zij democratisch wordt beslist en ingegeven en begrensd wordt door het belang van de burgers van het land.

4. De taken van het Hof zijn ook gewijzigd in die zin dat niet alleen de cassatieberoepen anders worden behandeld dan in het verleden maar ook in die zin dat het Hof een aantal opdrachten gekregen heeft van eerder administratieve aard die te danken zijn aan zijn unieke positie in het land en zelf een invloed hebben gehad op de wijze waarop het Hof het civiel cassatieberoep behandelt.

Het aantal bijzondere taken toevertrouwd aan het Hof, los van elk cassatieberoep, is kenmerkend gestegen. Die taken nemen een stijgend deel in van de activiteiten van het Hof. 9 De procesbehandeling van die taken wijkt ook af van de gewone behandeling van de cassatieberoepen.

Illustratief kunnen volgende opdrachten en taken vermeld worden:

- Beslissingen over de rechterlijke organisatie: wrakingen, onttrekkingen, regeling van rechtsgebied

- Cassatieberoep en beroep in volle omvang in bepaalde tuchtprocedures

- Nietigheidsberoepen bedoeld in de artikelen 609 en 6ro Ger.W.

- $\quad$ Controle over de werking van de hoven van beroep (artikel 398 Ger.W.)

- Beslechting van attributieconflicten

Het Hof neemt ook de laatste jaren meer en meer het voortouw in de verdediging van de taken en belangen die aan de rechterlijke orde zijn toevertrouwd en de kern van de rechtsstaat raken. Aldus coördineert het Hof in het kader van een 'vaste vergadering van de korpschefs van de hoven van cassatie en hoven van beroep' de actie van die korpschefs en heeft daarenboven talrijke initiatieven genomen in het kader van de informatisering van het justitiële apparaat.

Deze taken worden verder niet meer besproken in deze bijdrage.

\section{Cassatierechtspraak en appelrechtspraak}

\section{I De rechtsvormende en de corrigerende taak}

5. Het Hof heeft een tweeledige taak:

I. waken voor de juiste toepassing en interpretatie van de wet;

2. erop toezien dat de beslissing van de betrokken rechtscolleges in overeenstemming is met de vereisten van een goede rechtsbedeling. ${ }^{\text {IO }}$

9. Zie hierover I. Verougstraete, 'Een eerlijk proces voor het Hof van Cassatie, in: Liber amicorum Van den Berghe, Leuven 2007.

Io. H. Lenaerts, 'Cassatierechtspraak vandaag', Publicatie Staatsblad, p. 8. 
De eerste taak - die de zorg voor de rechtseenheid, de rechtszekerheid ${ }^{\mathrm{II}}$ en de rechtsevolutie bevat - is, zeker in de ogen van het Hof, de belangrijkste, ook al wijst de praktijk soms uit dat de kamers van het Hof meer aandacht schenken aan de eisen van een goede rechtsbedeling dan wel aan een harmonisererende of normerende opdracht. De problemen van een goede rechtsbedeling zijn overigens vaak eenvoudiger op te lossen dan de problemen van normatieve aard.

Die evolutie is merkwaardig, gelet op de wording van het Hof van Cassatie. Cassatie had tot doel, in het begin, de wet tegen interpretatie door de rechter te beschermen. Zoals Robespierre het uitdrukte, 'Le tribunal de cassation n'est point le juge des citoyens mais le protecteur des lois, le surveillant et le censeur des juges, en un mot, il est placé en dehors de l'ordre judiciaire et au-dessus de lui pour le contenir dans les bornes et dans les règles où la Constitution le renferme'. ${ }^{\mathrm{I} 2}$

Die extreme opvatting dat een Hof van Cassatie alleen maar ervoor moest waken dat de rechters door de uitlegging van de wet de wet niet zouden perverteren en de Grondwet in gevaar brengen, werd niet volledig gehandhaafd, ook niet in Frankrijk zodat in I80o al kon gezegd worden: 'L'objet essentiel de cet établissement est de conserver l'intégrité des formes judiciaires, de maintenir l'exacte observation des lois, de porter dans tous les tribunaux de la République cette uniformité de jurisprudence qui sera sans doute un des grands bienfaits de notre révolution.' 13

In het Belgische Congres van I832 zegt Mathieu Leclercq: 'La cassation n'est point instituée dans l'intérêt des plaideurs; elle est créée uniquement, exclusivement pour maintenir l'unité de la législation par l'unité de la jurisprudence, pour parvenir progressivement en faisant ressortir tous les vices dans ses arrêts.' ${ }^{\text {I4 }}$

Die strekking tot rechterlijke regelgeving bestaat niet alleen in het Hof van Cassatie maar kan ook soms bespeurd worden in de huidige rechtspraktijk waarin het fenomeen Magnaud of de tendens tot eigenzinnigheid niet onbestaande zijn. Voor het Hof van Cassatie makt die beperkte regelgeving deel uit van een wezenlijke opdracht. Die taak drukt het Hof symbolisch uit door het gebruik van een apodictische stijl.

In een nomocratische maatschappij, dit is een samenleving opgevat als een interactieproces tussen soevereine actoren, moet het recht een minimale orde scheppen. De wetgever kan onmogelijk die mate van vaardigheid en kennis hebben dat alle mogelijke conflicten zouden geänticipeerd worden zodat de rechter onmisbaar blijft om de hiaten aan te vullen. Alleen in een teleocratische samenleving - maar dat is niet het model dat thans in Europa leeft - is de rechter overbodig omdat de enige

II. Rechtszekerheid is als dusdanig niet voldoende: in een staat zonder vrijheid kan er een absolute rechtszekerheid bestaan. Over de concepten zie L. François, 'La fiabilité du droit, dite sécurité juridique', in: La sécurité juridique, Ed.JB Liège, I993, 9-I9. De rechtszekerheid is ook een doel dat de rechters moeten nastreven: zoals L.François het treffend uitdrukt, 'il n'en est pas moins vrai que si les juges entendent non seulement en imposer le respect à d'autres autorités, mais aussi la respecter eux-mêmes, ils doivent veiller à ne pas trop se rendre imprévisible' (op. cit. p. 17).

I2. Marty, La distinction du fait et du droit, nr. 35 .

13. Abrial, geciteerd door G. Marty, La distinction du fait et du droit, essai sur le pouvoir de contrôle de la Cour de cassation sur les juges du fait, thesis Sirey 1929, nr. 35.

I4. B.S. 9 juni I832, eerste en tweede kol. 
vraag is hoe de doelstellingen de machthebber kunnen worden gerealiseerd. ${ }^{15}$ In het huidig model is het Hof van Cassatie een kernelement van onze nomocratische maatschappij.

Handhaving van subjectieve rechten in de rechtspraak van het Hof was nochtans niet onbelangrijk. Reeds in 1832 lieten bepaalde congresleden gelden dat het Hof van Cassatie een meer genuanceerde taak had dan alleen normatief op te treden. Jonet zegt: 'Les recours en cassation, dit-on encore, sont moins établis dans l'intérêt privé des parties que dans l'intérêt de toute la société. Je ne puis admettre cette proposition: le recours en cassation est établi dans l'intérêt public, cela est vrai, mais il l'est encore dans l'intérêt des parties. Si l'objection que l'on nous pose était vraie, il ne faudrait accorder la faculté du pourvoi qu'au seul Ministère public. ${ }^{\text {I6 }}$

De taak van het Hof is niet eenduidig omschreven, maar het volgende staat vast: het Hof van Cassatie werd bij zijn ontstaan gezien als een rechterlijke instantie die niet zozeer een beslissing gaf in een concrete zaak alswel oordeelde over de juiste toepassing van de wet. In het stelsel waarin het Hof van Cassatie was geconcipieerd, is het een controlerende instantie geplaatst buiten en boven de gerechtelijke instanties, waaraan de beslissing der gedingen is opgedragen (juges du fond), die nimmer kan kennis nemen van de zaak ten gronde en er zich toe moet beperken juridisch foute vonnissen te vernietigen met verwijzing van de zaak naar een 'juge du fond'. ${ }^{17}$

Fundamenteel is er voor het Hof niet enorm veel veranderd de laatste 175 jaar. $^{\text {I8 }}$ Zoals Faye het schreef: 'ses justiciables ne sont pas en réalité les parties, dont l'intérêt n'est qu'accessoirement engagé devant elle, mais les arrêts envisagés uniquement dans leurs rapports avec la loi. Elle tient donc pour constants les faits reconnus par les juges et l'interprétation qu'ils ont donnée aux conventions d'après l'intention des contractants; elle n'a qu'à rechercher si, en présence de ces éléments admis comme certains, la loi a été exactement appliquée.'Ig

\subsection{Elk zijn opdracht: tussen recht en feit}

\subsubsection{Algemeen: de aard van de opdrachten}

6. De taak van de hoven van beroep (als appelrechtspraak) verschilt kennelijk van de taak van het Hof van Cassatie, althans wat het klassieke cassatieberoep betreft. ${ }^{20} \mathrm{De}$ hoven van beroep (of de appelrechters in het algemeen) toetsen de beslissingen die hen worden onderworpen in volle omvang en hebben zelfs via de versterkte devolu-

I5. B. Bouckaert onderstreept dat de huidige nomocratische modellen in zekere mate ook teleocratische elementen inhouden en dat er zo een osmose ontstaat (p. 9).

I6. Kamer 7 juni I832, BS 9 juni I832, p.I344, $2^{\mathrm{e}} \mathrm{kol}$.

I7. Zie W.E. Haak, 'De evolutie op lange termijn van de Nederlandse cassatieprocedure in burgerlijke zaken sedert I8 38 ', in: 175 jaar Cassatie, Larcier, in druk.

18. Zie voor de historische evolutie J. Boré en L. Boré, La cassation en matière civile, Dalloz 2003, I-22.

19. Faye, La cour de cassation. Traité de ses attributions et de sa compétence et de la procédure observée en matière civile, Ière éd. Chevalier-Marescq, I903, p. I2.

20. Het Hof van Cassatie neemt kennis van feiten onder meer bij de nietigheidsberoepen ex artikel 6ro Ger.W. of bij vorderingen tot onttrekking. 
tieve kracht van het hoger beroep de mogelijkheid om het geding in eerste aanleg voor een deel overbodig te maken.

Wat de feitenrechters vooral kenmerkt is dat zij bepaalde feiten al dan niet bewezen verklaren of aannemen en daaruit de rechtsgevolgen trekken. ${ }^{2 \mathrm{I}}$

Het Hof van Cassatie moet dus niet het recht toepassen op feiten, althans dit lijkt zo te zijn. Die bewering klinkt wat vreemd, althans bij een eerste lezing, omdat de rechter die de toepassing van de feiten op het recht controleert in wezen ook feiten beoordeelt. Die enigszins paradoxale opmerking belet niet dat het onderscheid tussen recht en feit nog steeds de basis vormt van de afscheiding tussen feitelijke instanties en het Hof van Cassatie.

7. Het onderscheid tussen recht en feit is een klassiek discussiethema waarover zeer veel geschreven is. ${ }^{22}$ Het onderscheid is fundamenteel, ook al is er conceptueel wel een probleem doordat het onderscheid feit-recht volledig overeenstemt met het onderscheid bevoegdheid van de feitenrechter-bevoegdheid van het Hof van Cassatie. Terecht kan er sprake zijn van enige contaminatie: de inhoud van het concept feit respectievelijk recht zal voor een deel bepaald worden door de inhoud die de geïnteresseerden willen geven aan de bevoegdheid van het Hof van Cassatie.

Ondanks de onzekerheden van het concept en de quasi onmogelijkheid om te bepalen wat de Grondwet bedoelt met de regel dat het Hof van Cassatie 'niet in de beoordeling van de zaken zelf treedt' (artikel I47 GW), en er dus geen echte dichotomie bestaat tussen feit en recht, is het onderscheid cruciaal voor de afgrenzing van bevoegdheid. Aangezien het Hof zelf bepaalt wat juist bedoeld wordt met resp. feit en recht bepaalt het in zekere mate zelf de grenzen van zijn bevoegdheid. ${ }^{23}$

Het onderscheid tussen recht en feit is ondertussen ook op andere vlakken belangrijk gebleken, in het bijzonder om de grenzen van het civiele geding te trekken. De discussie - die nog niet afgerond is - in verband met de draagwijdte van artikel 807 van het Gerechtelijk Wetboek en de 'reïficatie' van de vordering loopt enigszins evenwijdig.

\subsubsection{Praktische voorbeelden; geen ontologisch onderscheid}

8. De auto-regulering die aldus op dat vlak aan het Hof wordt gelaten is zichtbaar in een aantal materies waarin het scherp onderscheid tussen feit en recht verdwijnt.

Een van de meest opvallende voorbeelden is vermoedelijk de leer van het kort geding waarin het Hof met een constante logica de taak heeft omschreven van het

2I. Zie hierover F. Rigaux, La nature du contrôle de la Cour de cassation, Bruylant I966, p. 24, nr. I8; J.F. van Drooghenbroeck, Cassation et juridiction, Bruylant 2004, p. I45.

22. Alleen maar als voorbeeld: Ch. Perelman, 'La distinction du fait et du droit. Le point de vue du logicien', in: Le fait et le droit, Bruylant I96I; M. Van Quickenborne, Feit en recht, of de rechter en de procespartijen, Brussel-Swinnen I987; L. de Gryse en B. de Gryse, 'Recht of feit: een hanteerbaar onderscheid' in Liber amicorum Simont, Bruylant 2002, 7I-88: J.F. Van Drooghenbroeck, Cassation et juridiction. Iura dicit curia, Bruylant 2004, 27 sq.

23. Zie Jaarverslag van het Hof van Cassatie I997-98: 'Het Hof van Cassatie erkent ook zijn rechtsvormende taak binnen de grenzen die het zelf meent te moeten trekken' (p. 39). 
Hof van Cassatie in kort geding. ${ }^{24}$ De constante die terugkomt is dat het Hof van Cassatie de beoordeling in rechte van de feitenrechter (die een voorlopige beoordeling mag doen in het kader van het afwegen van belangen) alleen marginaal toetst en dus oplossingen die juridisch niet onredelijk zijn aanvaardt in zoverre de kortgedingrechter in dit verband geen declaratoir van rechten heeft gedaan of de rechtspositie van de partijen niet onherroepelijk heeft gewijzigd. Het Hof van Cassatie treedt in zoverre in het domein van de feiten in de mate het bepaalt in hoeverre de kortgedingrechter mocht anticiperen op de eindbeslissing. ${ }^{25}$ En passant heeft het Hof op een bepaald ogenblik de toets van de motivering ook enigszins gemilderd. ${ }^{26}$

\section{De kloof tussen feit en recht lijkt meer instrumenteel te zijn dan ontologisch.}

Hoe kunnen wij anders het statuut in 's Hofs rechtspraak van het buitenlandse recht uitleggen dat noch recht noch feit is $?^{27}$ Het Hof oordeelt dat het een zekere controle kan uitoefenen - en dus dat het buitenlandse recht geen zuiver feit is - maar de toenemende inbreng van vrij complexe vreemde rechtsstelsels in de nationale gedingen, leidt ertoe dat de controle van de toepassing door de feitenrechter van het buitenlandse recht steeds beperkter wordt.

Zo ook zijn algemene rechtsbeginselen elementen van het recht, zodat het Hof gedragingen aan ongeschreven regels kan toetsen. ${ }^{28}$

Het Hof gaat uit van de feiten die de 'feitenrechters' hebben aangenomen. Het Hof mag de feiten zelf niet gaan opzoeken en beoordelen. Maar een mate van beoordeling van de feiten die de gewone overname en selectie van feiten overstijgt is aanwezig.

Het Hof beoordeelt immers duidelijk de feiten waar het zegt dat het zelf mag oordelen of de feitenrechter uit de door hem vastgestelde feiten de gevolgen heeft kunnen trekken die hij getrokken heeft. Dit komt ook neer op wat J. Ronse kwalificeerde als de marginale toetsing, dit is een beperkte beoordelingsvrijheid die zich in het midden bevindt tussen het geheel ontbreken daarvan en de volledige toetsing waarbij de rechter zonder meer de aan hem onderworpen gedraging of rechtshandeling beoordeelt volgens zijn eigen maatstaven omtrent wat behoorlijk of onbehoorlijk is. ${ }^{29}$

24. Zie Cass., 22 februari I99I, A.C. I99I, 34I; Cass. I3 mei I99I, A.C., nr. 469; Cass. 4 juni I993, A.C. I993, 269; Cass., 23 december 1994, A.C. I994, nr. 575; Cass. I6 november 1996, AC I996, nr. 454; Cass. 3 I januari I997, AC I997, nr. 56; Cass. 4 februari 2000, TBH 2000, p. I84.

25. Voor een ruime bevoegdheid in dit verband, zie I. Verougstraete, 'het kort geding-recente trends', TPR I980, p.267; J. Laenens, 'Kroniek van het gerechtelijk recht, I983-84', RW I984-85, I760.

26. Zie noot AS Maertens onder Cass.I4 juni I99I, TBH I992, 257.

27. Zie over de evolutie van de rechtspraak van Cassatie L. Simont, 'La Cour de cassation et la loi étrangère. Quelques réflexions', in: I. Verougstraete, C. Storck en G. Bresseleers (ed), Imperat lex, I89206. L. Simont wijst op de nogal verwarrende rechtspraak van het Hof van Cassatie... dat aldus wel bewijst dat het zichzelf reguleert.

28. Zie A. Bossuyt, 'Algemene rechtsbeginselen', in: I. Verougstraete, J.F. Leclercq, P. Lecroart en S. Lierman, Jaarverslag van het Hof van Cassatie 2003, p. I24.

29. Zie hierover G.J. Wiarda, 'Drie typen van rechtsvinding', in: Een bundel gedachten, I963, I49; J. Ronse, 'Marginale toetsing in het privaatrecht', TPR 1977, 207; J. Ronse, 'Le contrôle marginal des décisions discrétionnaires en droit privé', in: La motivation des décisions de justice, Travaux du centre national de recherches de logique, 403; J.M. Polak, 'Marginale toetsing en algemene beginselen van behoorlijk bestuur, ondernemen en handelen', Liber amicorum Ronse,Story Scienia 1986, 4I; R. Soetaert, 'Rechstbeginselen en marginale toetsing', in: Liber amicorum Jan Ronse, Story Scientia I986, p. 5I-66; L. de Gryse en B. de Gryse, 'Recht of feit: een hanteerbaar onderscheid', in: Liber amicorum Lucien Simont, Brussel, Bruylant, 2002, 7I-88. Het concept werd streng beoordeeld door H. Lenaerts, 'Cassatierechter vandaag', cit. 
Het meest opvallende voorbeeld dat als een mantra terug te vinden is in de arresten van het Hof in verband met de onrechtmatige daad, is de controle op de beoordeling van de feiten. Het Hof toetst het gedrag van de dader zoals omschreven voor de feitenrechter aan rechtsregels (en zelfs ongeschreven rechtsregels die het zelf definieert) om erna te oordelen of de feitenrechter uit de gegevens die hij vermeldt wel terecht heeft kunnen afleiden dat de dader al dan niet onvoorzichtig of onbedacht had gehandeld.

Een ander praktisch voorbeeld kan dit verduidelijken. Artikel 3 EVRM verbiedt sancties te nemen die onmenselijk of vernederend zijn.

Het Hof toetst de ernst van de sanctie o.m. genomen door de tuchtorganen door te oordelen of de raad van beroep van het instituut van de bedrijfsrevisoren op grond van de door hem vastgestelde feiten wettelijk een dergelijke beslissing kon nemen.

Het Hof doet niet anders wanneer het oordeelt of een maatregel niet onevenredig is met de zwaarte van het feit, of in fiscale materies, wanneer de opgelegde boete of vermeerdering van de belasting niet onevenredig is met de fiscale inbreuk.

Een analoog geval waarin formeel twee normen worden geconfronteerd bestaat hierin dat het Hof oordeelt, wanneer twee normen met elkaar in strijd zijn, in welke mate de ene niet onevenredig is met het beoogde doel. ${ }^{30}$

\subsubsection{Hoe uit zich de specificiteit}

Io. De scheidingslijn tussen de feitenrechters en het Hof van Cassatie is dus minder groot dan gedacht, zelfs in het kader van het klassieke cassatieberoep, omdat het onderscheid feit en recht zelf geen scherp onderscheid toelaat.

Er is geen echte breuk tussen feitenrechters en Hof van Cassatie maar wel een andere opdracht. Als volgens de Grondwet gezegd wordt dat 'het Hof niet in de beoordeling van de zaken zelf treedt' (artikel I47 van de Grondwet) dan moet dit niet letterlijk worden opgevat en is dit meer een algemene omschrijving van de taken van het Hof dan wel een regel.

De rechtsverhouding tussen de partijen zoals zij door de feitenrechter is omschreven is voor de cassatierechter een vaststaand feit. ${ }^{3 \mathrm{I}}$ Zeker in civiele zaken - waar hij overigens geen ambtshalve middelen kan aanvoeren om de beslissingen te vernietigen - is het feitelijk kader dat hem wordt voorgelegd strak bepaald.

Die strakheid wordt geïllustreerd door de leer van het nieuwe middel. Nieuwe middelen zijn in beginsel voor het Hof verboden tenzij de eiser in cassatie onmogelijk een onwettigheid kon aanklagen in hoger beroep (bijv. wanneer de onwettigheid door de bestreden beslissing zelf voor het eerst is begaan) of wanneer het middel een schending aanvoert van een bepaling van openbare orde of van dwingend recht. ${ }^{32}$ De reden is dat de taak van het Hof van Cassatie hierin bestaat, zoals het Franse Hof

30. Cass. 20 juni I997, JT I998, 255.

3I. Dit geldt niet voor de juridische kwalificatie van de rechtsverhouding: dit bindt de cassatierechter maar in beperkte mate.

32. Over de nieuwe middelen, zie A. Meeus, 'La notion de loi impérative et son incidence sur la procédure en cassation et sur l'office du juge', noot onder Cass., I7 maart I986, RCJB I988, 498 sq. 
van Cassatie het omschrijft, 'apprécier la solution légale donnée aux moyens débattus devant le juge du fond'. 33

II. Gelet op die principiële beperking is het voor de cassatierechter van groot belang te weten met welke feiten hij rekening kan houden. ${ }^{34}$

De feiten die vaststaan, zijn in beginsel de feiten die door de appelrechter zijn vastgesteld en in de bestreden beslissing voorkomen. Hierin is begrepen de uitlegging gegeven door de appelrechters van de contracten gesloten tussen de partijen.

Die feiten die vaak elliptisch zijn weergegeven in het bestreden arrest laten niet altijd toe aan de cassatierechter te oordelen over de juistheid van de toepassing van het recht op de feiten, in de grenzen waarin dit kan gebeuren.

Het staat de partijen vrij ook bepaalde stukken neer te leggen, in zoverre ze de grenzen van het cassatieberoep en van de opgeworpen middelen niet overschrijden. Het dossier van de partijen die zij in de feitelijke instantie hebben neergelegd wordt niet neergelegd voor het Hof in civiele zaken met toch twee belangrijke uitzonderingen: in tuchtzaken en in fiscale zaken, wordt het dossier door de fiscus resp. door de tuchtoverheid neergelegd. Het is overigens opvallend hoe in die zaken het Hof van Cassatie zijn oordelen vrij nauw laat aansluiten bij de feitelijke omstandigheden.

\subsection{Rechters zonder grenzen: opperste gerechtshoven, transnationale gerechtshoven en grondwettelijk Hof}

I2. De werkwijze van het Hof van Cassatie als opperste gerecht contrasteert met de werkwijze zowel van het EHRM als van het Hof van Justitie en van het Beneluxgerechtshof.

I3. Het EHRM heeft wel een beperkte bevoegdheid maar vertoont geen drempelvrees over feiten. Om te oordelen of het recht op een eerlijk proces geschonden is, aarzelt het EHRM niet om zelf het proces als het ware te herbeginnen en redeneringen en feiten te betrekken die het Hof van Cassatie niet zou kunnen betrekken gelet op zijn bevoegdheid.

Dit is in het bijzonder gebleken in verband met de Franse zaken resp. over het nieuwe middel 35 en over de substitutie van motieven. ${ }^{36}$ In de eerste zaak heeft het EHRM zich volgens sommigen vergist in de oplossing (doordat het met miskenning van de regels kennis had genomen van bepaalde feitelijke omstandigheden en die feiten verkeerd beoordeeld heeft ${ }^{37}$ ).

33. Chambre des requêtes 25 november 1852 . Dit wordt in de hedendaagse Code de procédure civile (art.604) iets ruimer verwoord: 'Le pourvoi en cassation tend à faire censurer par la Cour de cassation la non-conformité du jugement qu'il attaque aux règles du droit'.

34. Zie hierover P.A. Foriers, 'La preuve du fait devant la Cour de cassation', in: Mélanges offerts à Ch. Perelman. La preuve en droit, Bruylant I98I, p. I23 sq.

35. EHRM I2 oktober I994, Fouquet, Rec.CEDH, I996-I, 25; EHRM 2I maart 2003, Rec.DS, nr. 43, 833888.

36. EHRM I3 oktober 2005; hierover JF Van Drooghenbroeck, 'La substitution de motifs astreinte à la contradiction', JT 2005, p. 677; zie ook EHRM I6 februari 2006, Prykyan en Angelova v. Bulgarije, JT 2006, 430, noot.

37. Zie hierover Boré, op. cit. 82.33. 
I4. Het Hof van Justitie heeft ook de neiging in prejudiciële zaken om de feiten te reconstrueren en het nationale recht op eigen gezag uit te leggen. Het Hof van Justitie houdt voor dat dit nodig is om een 'nuttig' antwoord te geven aan de verwijzende rechter. Dat is niet per se het geval, maar wat belangrijk is in deze context is dat het Hof van Justitie zich niet gebonden acht door de strakke regels waaraan het Hof van Cassatie bijvoorbeeld zich wil onderwerpen. De gegeven antwoorden gaan vaak verder dan de gestelde vragen of weigeren op bepaalde aspecten van de vragen in te gaan.

I5. Hetzelfde geldt voor het Belgische Grondwettelijk Hof in het kader van de zgn. streepjes-arresten. Als de verwijzende rechter de vraag stelt over de verzoenbaarheid van een wet of decreet met de Grondwet en zelf een uitlegging geeft aan die wet of dat decreet, ${ }^{38}$ dan voert het Grondwettelijk Hof soms een alternatief ter tonele aan: in een uitlegging a (bijv. waarvan de verwijzende rechter uitgegaan is) is er strijdigheid met de Grondwet maar in een uitlegging b (geoffreerd door het Grondwettelijk Hof) is er geen strijdigheid. De arresten van het Belgische Grondwettelijk Hof wagen zich in de regel niet verder dan dit alternatief zodat de rechter bij de eindbeslissing de volgende keuze heeft:I.ofwel de wettelijke bepaling lezen op een grondwetconforme wijze, desnoods nog via een andere lezing dan de oorspronkelijke door de verwijzingsrechter aangehouden uitlegging en dan de lezing gegeven door het Grondwettelijk Hof; 2. ofwel de strijdigheid vaststellen tussen de Grondwettelijke en wettelijke bepalingen en dan de wettelijke bepaling buiten toepassing laten; 3. de strijdigheid vaststellen en vervolgens in bepaalde grenzen de strijdigheid wegwerken door een deel van de wettelijke bepaling buiten toepassing te laten. ${ }^{39}$ Als de verwijzingsrechter het Hof van Cassatie is, betekent dit dat het geding zoals voor het Hof ingeleid een volledig nieuwe dimensie kan krijgen.

Dit alles wijst erop dat in het kader van het overwegend objectief contentieux waarin Grondwettelijk Hof en Hof van Justitie opereren, die rechtsinstanties zich niet gebonden achten door strakke grenzen of door een of ander beschikkingsbeginsel of beginsel van het gezag van het rechterlijk gewijsde. In een eigen logica achten zowel het Hof van Justitie als het Grondwettelijk Hof dat de verwijzingsrechter - ook al is het een opperste gerechtshof - bij de oplossing van de vraag niet mag stilstaan bij procesregels of regels van materiële recht wanneer die regels elk nuttig effect zouden ontnemen aan de beslissing van het Hof van Justitie resp.Grondwettelijk Hof. $4^{\circ}$

Dit laat sporen achter wanneer het Hof van Justitie ook optreedt als cassatierechter (in zaken van intellectuele eigendom, van mededinging). Het Hof van Justitie heeft enige moeite om die techniek te beheersen en treedt op als appelrechter in bijna volle

38. Soms omdat de partijen hem overigens geen andere oplossing aanreiken of het eens zijn dat die uitlegging de enige is die kan worden aangenomen.

39. Zie bijv. Cass., 8 oktober 200I, AC nr. 530; over de bruikbaarheid van het antwoord voor de verwijzende rechter zie ook de Leval, Horevoets en M.F. Rigaux, 'La pertinence de la question préjudicielle et l'usage de la réponse par le juge a quo', in: De verhouding tussen het Arbitragehof, de rechterlijke macht en de Raad van State, cit., p. $27 \mathrm{I}$. 
omvang ten opzichte van het Gerecht van eerste aanleg van de Europese Gemeenschappen (hierna: Gerecht). ${ }^{4 \mathrm{I}}$ De voorbeeldfunctie van het Europees gerechtshof wordt overigens in vraag gesteld ook om andere redenen dan de zwakke beheersing van de cassatietechniek. Stürner omschrijft de procedure voor het Hof van Justitie en schrijft als conclusie: Denn vor dem EuGH prozedieren nur öffentliche oder doch eher elitäre Parteien vor ausgewählten Richtern, nicht der gewöhnliche Bürger vor den gerichten des Alltags'. ${ }^{42}$

\section{De rol van de partijen}

I6. In een perspectief van objectief contentieux is het cassatieberoep niet bedoeld als een rechtspleging bestemd om de belangen van de partijen te vrijwaren, zoals de toekomstige PG Mathieu Leclercq het formuleerde in I832. ${ }^{43}$ De partijen zijn als het ware maar een interface naar het hoogste gerecht en hun geschil is maar een gelegenheid voor het Hof van Cassatie om het recht te zeggen. In de woorden van Faye, 'ses justiciables ne sont pas en réalité les parties, dont l'intérêt n'est qu'accessoirement engagé devant elle'. ${ }^{4}$

De eiser in cassatie die de zaak voorlegt aan het Hof en ook de grenzen bepaalt waarin het Hof kan kennis nemen van de zaak, is een belangrijk element in deze context, meer dan de verweerder. Het cassatieberoep kan immers al dan niet beperkt zijn, en het Hof kan geen ambtshalve middelen nemen in civiele zaken om de bestreden beslissing te vernietigen.

I7. Het is dan ook niet verwonderlijk dat er in de procedure geen eigenlijke verweerder is (ook niet de betekende) en verstek evenmin mogelijk is. Wie als verweerder wordt opgeroepen kan weliswaar zijn rechten laten gelden binnen bepaalde grenzen, maar hij is geen partij in de volwaardige zin van het woord.

Dit legt uit waarom de artikelen 774 en volgende, 794 en volgende van het Gerechtelijk Wetboek niet toepasselijk zijn. Als het Hof van Cassatie het debat heropent over gelijk welk punt, zal het zich nooit gedwongen voelen zitting te nemen in dezelfde samenstelling. Als het Hof een vergissing in een arrest rechtzet zal het

40. Voor het Hof van Justitie: I4 december I995, Petercam, Jur.I995, I-04599 en 7 september 2006, 470/04; voor het Grondwettelijk Hof: de cause célèbre van de belastingszaak beslecht door het Arbitragehof bij arrest van 3 juli 2002 en van het Hof van Cassatie van 20 maart 2003. Die zaak heeft gedemonstreerd dat het Grondwettelijk Hof en het Hof van Cassatie in feite zelf allebei de grenzen van hun bevoegdheid bepalen en dat zij dus absoluut conflicten moeten vermijden. Het beschikkingsbeginsel, de leer van het nieuwe middel, het gezag van het rechterlijk gewijsde, staan er niet aan in de weg dat het geding onverwacht een nieuwe dimensie krijgt. Dit wordt dan theoretisch verantwoord door de abstracte regel van de voorrang van het Europese recht of van het grondwettelijke recht op de gewone nationale norm.

4I. Zie hierover de Gryse, E. de Gryse, commentaar onder baby dry, TBH 2002, 363; T. van Innis en E. de Gryse; 'Les procédures devant la Cour de Justice et les décisions en matière de marques', Ing.Cons., I999, I59-I76.

42. R. Stürner, 'Zur Struktur des europäischen Zivilprozesses', in: Festschrift für Ekkehard Schumann zum 70. Geburtstag, 504.

43. Supra, rn. 5 .

44. Faye, cit., p. I2. 
evenmin de grenzen naleven van artikel 794 van het Gerechtelijk Wetboek. Het volledige Boek van het Gerechtelijk Wetboek over het geding is niet toepasselijk op het Hof van Cassatie tenzij soms per analogie.

Dit legt ook uit waarom het overlijden van een partij geen enkele wijziging brengt aan het verloop van het geding (het overlijden van een advocaat bij het Hof van Cassatie hangende het geding heeft evenmin enig gevolg).

I8. Dit neemt niet weg dat ook in het Hof van Cassatie de eisen van het eerlijk proces prevaleren en dat mitsdien bepaalde waarborgen van het subjectief contentieux stilaan ingeburgerd worden in het Hof. De formele procesregels die de rechtspleging van het Hof beheersen zijn - dit is een zegen - zeer gering in aantal en uiterst kort geformuleerd in de wetgeving. Het Hof van Cassatie is ontsnapt aan de hervormingen die het parlement heeft doorgevoerd aan het Gerechtelijk Wetboek dat na veertig jaar verwarrende amenderingen geen coherent beeld meer vertoont.

De procedure gebeurt in beginsel schriftelijk met het neerleggen van een verzoekschrift en de mogelijkheid voor de verweerder om een memorie neer te leggen (artikel 1093 Ger.W.).

De verweerder wordt dus wel degelijk erkend en het Hof heeft het recht niet, wanneer de verweerder niet optreedt, een arrest te wijzen vooraleer de drie maanden verstreken zijn waarop de verweerder recht heeft om te antwoorden. 45

De eiser krijgt daarenboven de kans een repliek te geven op de memorie in zoverre de verweerder een middel van niet-ontvankelijkheid van het cassatieberoep heeft opgeworpen ${ }^{46}$ en ook in zoverre het Openbaar Ministerie een niet-ontvankelijkheid van het cassatieberoep opwerpt. 47

Tot dusver was dit maar een beperkte stap naar een volwaardig contradictoir debat. De wet van I4 november 2000 is een volgende stap.

De partijen krijgen bijkomende rechten. Zij kunnen kennis nemen van de geschreven conclusie van het openbaar ministerie (artikel II05 en II07 Ger.W.), en daarover een noot neerleggen. Zij kunnen na het openbaar ministerie in zijn conclusie te hebben gehoord, uitstel vragen of verzoeken over die conclusie een memorie neer te leggen (artikel IIog Ger.W.). ${ }^{48}$ Daarenboven aanvaardt het Hof van Cassatie dat de partijen een 'anticipatieve noot' zouden neerleggen waarin bepaalde facetten van hun middelen worden uiteengezet (dit wordt in praktijk vooral gedaan wanneer er een nieuwe wetgeving bestaat of een of ander merkwaardig feit zich heeft voorgedaan dat invloed kan uitoefenen op het geding (zie hierna meer gedetailleerd, nr. 22).

Een kwalitatief belangrijke stap is verder gezet door het Hof doordat het in zijn Jaarverslag 2006 verklaart aan te sluiten bij de grond van de rechtspraak Clinique

45. Dit is een ernstige leemte die de verweerders kunnen gebruiken in spoedeisende zaken om te beletten dat het Hof op korte termijn zou beslissen.

46. Die innovatie dateert maar van 25 februari 1925 , maar werd reeds in praktijk toegepast (zie Pasin I925, p. 43 e.v.).

47. Innovatie van 20 juni i953 en ro oktober 1967.

48. Volgens de letter van artikel IIo7 Ger.W. uitsluitend wanneer er een formele schriftelijke conclusie is van het openbaar ministerie. In werkelijkheid wordt altijd toegelaten te reageren, ook wanneer de conclusie louter mondeling was. 
Acacia. ${ }^{49}$ Dit betekent met andere woorden dat minstens in het geval van een substitutie van motieven het Hof ertoe neigt om de beide partijen hiervan te verwittigen (voor het arrest gewezen is). Dit is een stap naar de erkenning van een subjectief contentieux.

Een andere kwalitatief belangrijke evolutie is het feit dat het Hof, wanneer het een beslissing vernietigt, steeds antwoordt op gronden van niet-ontvankelijkheid van het middel opgeworpen door de verweerders. Het Hof doet dit niet omdat het op redenen die in memories zijn opgenomen moet antwoorden maar wel als toets voor de stevigheid van zijn rechtspraak.

Die stappen naar de subjectivering mogen nochtans niet de indruk wekken dat de taak van het Hof van Cassatie, door die betere bescherming van de betrokkenen, fundamenteel gewijzigd is. De kern blijft wel degelijk dat er geen ware partijen zijn voor het Hof. Natuurlijk kan de vermenigvuldiging van die kleine stappen leiden naar een nieuwe kijk op het geding in cassatie. Die vermenigvuldiging kan, mede onder druk van het EVRM, ertoe leiden dat voor het Hof van Cassatie een echt debat wordt gevoerd tussen partijen (in civiele zaken).

Het gevaar is niet denkbeeldig dat hierdoor de aard zelf van de taak van het Hof wordt aangetast en dat de aandacht teveel zal worden afgeleid naar de directe zorgen van de partijen. De partijen zijn belangrijk maar zijn niet de enige inzet.

I9. Nieuwe stappen zijn nog denkbaar in de richting van het 'eerlijk' proces zonder dat hierdoor de taak van het Hof wordt geperverteerd.

Het Hof verwerpt cassatieberoepen om de meest diverse redenen, maar geeft aan de partijen in de regel niet de gelegenheid om te reageren op een voorgenomen verwerping, zelfs niet wanneer geen verweerder is komen opdagen of wanneer het openbaar ministerie die grond van verwerping niet heeft aangereikt.

Het is alleen bij een substitutie van motieven dat in beginsel aan de partijen de gelegenheid wordt gegeven te reageren op de voorgenomen substitutie en geeft aan de partijen de gelegenheid op voorhand te reageren wanneer het een substitutie van motieven doorvoert.

Die aparte behandeling uitbreiden tot alle mogelijke gevallen van verwerping zou leiden tot een volledig nieuwe procedure waarin het recht op tegenspraak het geding in cassatie zou doen evolueren naar een bijzondere vorm van derde aanleg. Het zou indruisen tegen de aard zelf van het cassatieproces, en zou de noodzaak creëren van een volledig nieuw concept.

Als de eigen aard van het cassatiegeding moet bewaard blijven zijn er andere stappen die kunnen gezet worden en vermoedelijk productiever zijn dan het Hof te verplichten de werkmethodes van de feitenrechters te volgen. Aldus zou het moeten kunnen dat het Hof op voorhand aan de advocaten van de partijen laat weten dat het een bijkomende uitlegging wenst op een bepaald punt. Het Hof kent lang voor de zitting, soms maanden op voorhand, de knelpunten die tijdens het beraad zullen

49. Zie Hoofdstuk VI - De procedurele aspecten van de substitutie van motieven door het Hof van cassatie in burgerlijke zaken (I8I) I94. 
besproken worden. Het zou kunnen overwogen worden dat occasioneel de partijen een bijkomende toelichting zouden mogen geven op punten die het Hof aanwijst.

Dat de partijen op voorhand moeten worden ingelicht over die vragen ligt voor de hand. Zouden de advocaten in die procedures die in wezen schriftelijk zijn zich telkens voor de openbare zitting opnieuw moeten voorbereiden in alle zaken, dan zou dit een te grote kostprijs hebben. Zij moeten zich desgevallend gericht kunnen voorbereiden. Die wijziging vraagt geen wetswijziging.

\section{$4 \quad$ Rechtsgebied, procesregels en werkwijze; feiten en ambtshalve aanvullen van gronden}

\section{I Het civiele proces in cassatie}

20. De objectieve aard van de rechtspleging - getemperd door beginselen die meer rechtstreeks de partijen aanbelangen - heeft van bij de aanvang de aard van die rechtspleging bepaald..$^{\circ}$ De rechtspleging is hoofdzakelijk schriftelijk, de termijnen die aan de partijen worden gegeven om te concluderen of te repliceren (en de voorwaarden om dat te doen) zijn uitermate strak, terwijl het openbaar ministerie en het Hof zelf aan geen enkele termijn gebonden zijn. ${ }^{5 \mathrm{I}}$

De mogelijkheid van repliek is gegeven aan de verzoeker in cassatie door een wet van 25 februari 1925 en was beperkt tot de mogelijkheid te antwoorden op een middel van niet-ontvankelijkheid.

Wat hiervoor gezegd werd, geldt alleen voor de civiele gedingen (in de brede zin van het woord: fiscaal recht, administratief recht; handelsrecht en alle takken van het privaatrecht). Ook het fiscaal recht is hierbij betrokken, hoewel tot een vijftig jaar geleden het fiscaal recht voor het Belgische Hof van Cassatie behandeld werd als een penale materie.

De aard van het proces in cassatie in civilibus wordt gedetermineerd door de combinatie van het beschikkingsbeginsel en door de objectiverende aard van het geding. Uit die combinatie volgt een strakke regeling voor de cassatieberoepen..$^{2}$ Dit vraagt een vrij grote discipline van de leden van het Hof die én strafzaken afhandelen én civiele zaken, aangezien in strafzaken die strakheid veel minder bestaat, het recht van verdediging zeer ruim wordt uitgelegd en de regels veel soepeler worden toegepast. ${ }^{53}$

50. Zie hierover o.m. J. van Compernolle, 'Contradiction et égalité des armes dans l'instance de cassation: une évolution inachevée?’, in: 175 jaar Hof van Cassatie, Larcier 2007 (in druk).

5I. Ook niet na een wat merkwaardige wetgeving over de gerechtelijke achterstand die volledig aan het Hof is voorbijgegaan: wet van 26 april 2007. Zie over deze wet o.m. A. Bouché, 'La mise en état des plaidoiries', JT 2007, 553; D. Scheers en P. Thiriar, Het gerechtelijk recht in de hoogste versnelling, Antwerpen-Intersentia, 2007, p. 3-97.

52. Voor de civiele materies die het Hof behandelt buiten het kader van het eigenlijke cassatieberoep is de toestand anders. Zie hierover I. Verougstraete, 'Een eerlijk proces voor het Hof van Cassatie', in: Liber amicorum $\mathrm{H}$. Van den Berghe, in druk.

53. En typisch voorbeeld: in civiele zaken wordt geen rekening gehouden met de toelichting, in strafzaken is de vorm waarin het verweer wordt geformuleerd zonder veel belang. 
Die complexiteit is traditioneel. Zij stoort niet omdat een gespecialiseerde balie bij de redactie van de cassatieberoepen intervenieert (zowel als eiser als verweerder) en de technische regels helpt handhaven. Die strakheid is een hulp bij het besef dat de taak van het Hof van Cassatie essentieel van quasi-normatieve aard is. Dit quasinormatieve is wellicht van minder relatief belang in de strafzaken.

\subsection{Werkwijze en denkproces van het Hof van Cassatie: de vijf toetsen}

2I. De graad van abstractie - gesymboliseerd door de apodictische stijl van het Hof is een duidelijke ondersteuning voor het besef dat de cassatierechtspraak vooral dient om de rechtsnorm te handhaven. Zonder die apodictische stijl zou de neiging om beter aan te sluiten bij de concrete noden van de rechtsbedeling een stuk groter zijn.

De werkwijze van het Belgische Hof van Cassatie en de denkprocessen van dit Hof kunnen getoetst worden aan vijf aspecten:
a. hoe verloopt de procedure
b. in welke mate zijn de feiten belangrijk
c. hoe redeneert de cassatierechter
d. hoe motiveert hij zijn beslissingen
e. in welke mate spelen waardeoordelen een rol.

\subsubsection{Hoe verloopt de procedure}

22. Het verloop van de procedure is gekenmerkt door een (ononderbroken) tijdslijn en door de klemtoon op de schriftelijke procedure.

De procedure wordt ingeleid door het neerleggen van een (vooraf betekende) verzoekschrift dat de middelen bevat. De middelen moeten de geschonden wetsbepalingen duidelijk aanwijzen. De verweerder mag binnen een termijn van (in beginsel) drie maanden een memorie van antwoord neerleggen en de eiser in cassatie mag slechts een repliek (of memorie van wederantwoord) neerleggen wanneer een middel van niet-ontvankelijkheid van het cassatieberoep wordt opgeworpen. 54

De rapporteur wordt door de bevoegde afdelingsvoorzitter aangesteld en bestudeert het dossier, in voorkomend geval in samenwerking met een referendaris. Het openbaar ministerie onderzoekt ook het dossier op grond van de eerste bevindingen van de rapporteur. Wanneer een en ander klaar zijn, stelt de afdelingsvoorzitter de zaak vast voor de behandeling in openbare terechtzitting. Op die zitting wordt in beginsel niet gepleit (de advocaten bij het Hof van Cassatie zijn niettemin meestal aanwezig) maar neemt het openbaar ministerie een mondelinge conclusie. Hierna volgt een beraad en meestal uitspraak dezelfde dag. ${ }^{55}$

54. In de praktijk worden uitzonderlijke pleitnota's getolereerd. Dit zijn korte schriftelijke beschouwingen over een punt waarover de partijen niet gerust zijn, bij voorbeeld wanneer een nieuwe wetgeving of een kentering in de rechtspraak worden waargenomen.

55. De leden van de kamers krijgen kennis van het concept van arrest, met een vaak uitvoerige noot en documentatie van de rapporteur, meer dan een maand voor de zitting en de zgn. 'varianten' worden over en weer gewisseld tussen de raadsheren voor de openbare terechtzitting. 
In die sfeer met die talrijke onderlinge controles is er weinig ruimte voor uitvoerige essayistische pogingen in de redactie van het concept.

Het feit dat het voor de partijen ook fundamenteel gaat om een 'one shot' operatie zonder mogelijke correcties later verplicht hen ook één redenering op te bouwen tot staving van het cassatieberoep en, als er subsidiaire redenen zijn, die ook als dusdanig onmiddellijk te presenteren.

\subsubsection{In welke mate zijn de feiten belangrijk}

23. Feiten zijn in elke zaak belangrijk omdat zij rechtstreeks aansluiten bij een natuurlijk gevoelen van billijkheid en evenwicht dat ook leeft bij cassatierechters. De feiten die het Hof van Cassatie kent zijn beperkt en gekleurd door het prisma van de 'juge du fond': alleen die feiten die de appelrechter kende en neerschreef zijn gekend of worden geacht gekend te zijn. De stukken die de partijen nog mogen bijbrengen of de dossiers in fiscale zaken en tuchtzaken (met een onzeker statuut) vormen hierop de uitzondering.

Vooral de ervaring met die twee laatste soorten zaken betekent dat de formalistische aanpak om geen stukken toe te laten niet zo aantrekkelijk is, hoewel die strenge aanpak nuttig is om aan jonge leden van het Hof een empirische ervaring te geven van wat een bijna zuivere beoordeling in rechte uitmaakt. Het Hof legt zelf de grenzen van de feitenbeoordeling en het zou wellicht handiger zijn aan de partijen een zekere vrijheid te laten stukken neer te leggen zoals zij dat wensen. Er is weinig gevaar dat dit het Hof zou in verleiding brengen om zelf in de beoordeling van het feit te treden.

De onomkeerbare evolutie naar het elektronisch dossier betekent overigens in elk geval dat zelfs de bewijsstukken van de partijen meer en meer een elektronische vorm zullen aannemen en in elk geval door de cassatierechter zullen kunnen worden geraadpleegd. Het is voorspelbaar dat de partijen, zodra het elektronisch dossier er zal zijn, hun bewijsstukken elektronisch zullen voegen bij hun processtukken voor de feitelijke instanties zodat de cassatierechter ze steeds zal kunnen inkijken.

Het Hof begeeft zich evenwel niet op de paden van een feitelijk onderzoek of van een nieuwe beoordeling ongeacht wat aan het Hof wordt voorgelegd.

Voor gewone cassatieprocedures wordt hier nochtans uitzondering gemaakt voor één bepaalde soorten van feiten, dit is het effectief verloop van de procedure voor de feitenrechter. Het Hof onderzoekt de regelmatigheid van de procedure op grond van alle elementen van het dossier van de rechtspleging zoals dat wordt gedefinieerd in het Gerechtelijk Wetboek.

In bepaalde gevallen wordt het Openbaar Ministerie op het pad gestuurd van het feitelijk onderzoek (onder meer wanneer de griffie van een Hof van beroep duidelijke vergissingen heeft begaan in het versturen van het dossier, enz.)

Die theoretische duidelijkheid belet niet dat in zekere mate feiten een rol spelen bij het lezen van het middel. Middelen mogen niet ambtshalve worden aangevoerd in cassatie (in civilibus) maar dit belet niet dat een middel vaak op meer dan één wijze kan worden gelezen en dat naar gelang het geval het middel streng kan beoordeeld worden of iets ruimer. Wanneer het middel onduidelijk is, kan het als niet-ontvankelijk worden verworpen, maar het Hof zal iets sneller geneigd zijn aan te nemen dat 
een middel vaag en dus onontvankelijk is wanneer de bestreden oplossing kennelijk beantwoordt aan de verwachtingen van elke redelijke justitiabele en dus best wordt gehandhaafd.

\subsubsection{Hoe redeneert de cassatierechter}

24. De norm wordt vooral gehandhaafd door de wijze waarop het Hof redeneert.

Op het eerste gezicht is de redenering in een goed arrest steeds dezelfde:

Major is de wettekst of het algemeen rechtsbeginsel dat het dictum van het Hof zal gronden.

In de major wordt die algemene norm verder uitgewerkt of gedeeltelijk geconcretiseerd naar de casus toe.

In de minor wordt gezegd wat de 'juge du fond' beslist heeft. De conclusie ligt dan voor de hand: verwerping of cassatie.

De moeilijkheid ligt altijd in de uitwerking van de Maior, en daar ligt de creativiteit van het Hof of zijn inbreng in het recht.

Om te komen tot die uitwerking zijn meestal een aantal complexe redeneringen vereist, die leiden tot de concretisering van de norm. Het denkproces doet denken aan een binaire vorm van redenering ${ }^{6}$ of van trial and error. Het resultaat is een apodictische motivering waarin de cassatierechter de oplossing voorstelt als de enige logische. Een essayistische opbouw ${ }^{57}$ waarin de rechter zijn redenering opbouwt in een compleet verhaal zou best mogelijk zijn en komt overigens vaak voor in de noten die de rapporteurs maken als voorbereiding van hun arrest. Dit is niet de keuze die het Hof voor de eindredactie gemaakt heeft in de voorbije decennia, hoewel het geen moeite zou kosten om de arresten op die wijze voor te stellen.

\subsubsection{Hoe motiveert de cassatierechter zijn beslissing}

25. In beginsel is het Hof verplicht zijn beslissingen te motiveren: de verplichting opgelegd aan de rechter zijn beslissingen te motiveren (artikel I49 van de Grondwet) is ook toepasselijk op het Hof van Cassatie. De grondwettelijke verplichting moet echter concreet worden ingevuld en is niet dezelfde voor de feitenrechter en voor de cassatierechter. De motivering van de feitenrechters moet ook dienen om aan het Hof van cassatie toe te laten na te gaan of de feitenrechter juist heeft geoordeeld, terwijl dit zonder belang wordt per definitie wat het Hof van Cassatie betreft.

De wijze waarop het Hof zijn beslissingen motiveert, voldoet waarschijnlijk niet volledig of helemaal niet aan de verzuchtingen van de partijen die vermoedelijk wat meer uitleg zouden appreciëren..$^{8}$ De reden hiervoor ligt voor de hand: de

56. I. Verougstraete, 'Het Hof van Cassatie en de motiveringsplicht', in Mélanges offerts à Pierre Van Ommeslaghe, I07I.

57. In de woorden van Rogier De Corte, 'De eerste 175 jaar van het Hof van Cassatie', in: 175 jaar cassatie, Larcier, 2007 (in druk).

58. Voor een scherpe kritiek op de apodictische stijl, zie A. Touffait en A. Tunc, 'Pour une motivation plus explicite des décisions de justice et notamment de celles de la Cour de cassation', in RTDC I974, 32 sq. 
procespartijen zijn niet op het voorplan van de bekommernissen van het Hof, wel het recht.

Cruciaal is de eis dat de rechtspraak volledig rationeel zou zijn (wat meteen meestal inhoudt dat zij ook transparant zal zijn, want begrijpelijk voor de rationele geest). Rationaliteit en transparantie zijn verzoenbaar met de huidige stijl van de arresten van het Hof wat niet betekent dat alle arresten even geslaagd zijn of geen cruciale stap overslaan in de redenering.

Voor de transparantie (en zelfs rationaliteit of cohesie) is wellicht iets meer vereist. Walter Van Gerven pleitte reeds lang geleden voor een vermelding van de alternatieven in 's Hofs rechtspraak59 en Rogier De Corte sluit hierbij aan in zijn 'I75 jaar'. Volgens beide auteurs heeft het Hof moeten kiezen, in de arresten, tussen alternatieven (zie hiervoor de binaire gedachtengang van het Hof) en die keuze zou moeten duidelijk gemaakt worden. Die stelling lijkt mij nochtans overmatig uit te gaan van een procedure tussen partijen (waarbij aan de verweerder in cassatie ook een belangrijke rol is toebedeeld, terwijl de verweerder vaak geen stelling laat blijken). De alternatieven zouden met voldoende duidelijkheid moeten blijken uit de weergave van de bestreden beslissing en van de middelen aangevoerd door de eiser in cassatie.

Nochtans is de huidige toestand wat de transparantie betreft niet echt bevredigend. R. Soetaert pleitte reeds in I99I voor de vermelding in de arresten van een omgaan van rechtspraak. Thans wordt dat omgaan (meestal) vermeld in het Jaarverslag van het Hof maar de voorzichtige stijl van dit jaarverslag laat niet altijd toe de juiste draagwijdte van het arrest te situeren.

R. de Corte citeert in zijn 'De eerste 175 jaar van het Hof van Cassatie' een arrest van de Hoge Raad van 29 april 1992 waarin de Hoge Raad een keuze maakt tussen twee benaderingen en wel in de volgende woorden: 'Aldus past deze wet in de deformaliseringstendens welke in de rechtspraak tot uiting komt. Een en ander heeft ertoe geleid dat de Hoge Raad het bij genoemde wet ingevoerde art. $93 \mathrm{Rv}$. aldus heeft uitgelegd dat het aantal gevallen waarin de rechter bij uitzondering de nietigheid van de dagvaarding moet uitspreken, zo beperkt mogelijk wordt gehouden'. Het is pas op 24 juli 2007 dat het Hof expliciet vermeldt in een arrest dat het omgaat: in de XXe eeuw was dat ondenkbaar en de signalen in dat verband werden alleen maar zijdelings weergegeven in de conclusies van het openbaar ministerie of nog, door het feit dat het Hof een voltallige zitting hield, wat op zich reeds een signaal was.

De uitbouw van de Belgische arresten kan aldus wat explicieter zonder daarom het goede van het apodictische ${ }^{60}$ te verliezen.

\subsubsection{Waardeoordelen?}

26. De waardeoordelen van het Hof zijn onbetwistbaar maar komen, juist wegens het apodictische, niet altijd voldoende tot uiting. In de meeste gevallen is het goed dat bepaalde waardeoordelen niet aan de oppervlakte komen: het beleid van II, 9, 5

59. W. Van Gerven, 'Creatieve rechtspraak', RW I997-98, 209; I. Verougstraete, 'Een nieuw soort rechters?’, in: Liber amicorum W.van Gerven, p. 77, inz. 89-9o.

6o. Apodictisch wordt hier niet begrepen in de afgeleide pejoratieve zin! 
of 3 magistraten kan in heel wat gevallen niet teruggebracht worden tot één bepaald en duidelijk waardeoordeel en in een stelsel zonder dissenting opinions komt het vaak voor dat het eindresultaat bereikt wordt om totaal uiteenlopende redenen die moeilijk kunnen worden uitgedrukt.

Een uitgepuurde vermelding van de wettelijke doelstelling die de cassatierechter wil bereiken is zeker niet overbodig in arresten met een groot gehalte aan normatieve inhoud.

Bouckaert wijst er terecht op dat 'de rechter zijn beslissing een Konzensfähigkeit' zal moeten geven door zijn persoonlijke beslissing te doen begrijpen als een deel van de ratio legis. Het oordeel moet aldusq worden geformuleerd dat 'die billig und gerecht Denkenden seiner eigenen Gesellschaft hier akzeptieren können und werden". Bouckaert nuanceert terecht de Esseriaanse benadering en onderstreept dat een verrijking met empirische elementen de rationaliteitscriteria moet preciseren, maar de stelling van Bouckaert lijkt mij juist.

In die zaken die vaak fel worden besproken is de neiging groot om alleen een kleine harde kern te vermelden. In moeilijke zaken wordt die strekking overigens ook waargenomen in het Grondwettelijk Hof dat zijn waar beleid kan omhullen met de mantra's van de gelijkheid.

\subsection{Ambtshalve middelen}

27. Uit het voorgaande volgt dat het Hof van Cassatie - in civiele zaken - wat gewrongen is in een keurslijf van traditie en van grondwettelijke en wettelijke regels. Dit is in het bijzonder merkbaar wanneer moet onderzocht worden welke middelen en gegevens hij kan gebruiken voor zijn beslissing.

Ik heb reeds gezegd dat het Hof geen middelen ambtshalve kan aanvoeren om een beslissing te vernietigen. Dit is een strenge vereiste, die indruist tegen de logica. In strafzaken mag een ambtshalve middel worden aangevoerd; in civiele zaken, met inbegrip van de tuchtzaken en fiscale zaken die de openbare orde raken, mag dat niet, terwijl de normatieve rol van het Hof precies in die zaken het grootst is.

De hand wordt streng gehouden aan de naleving van het voorschrift. Om te vermijden dat het Hof de neiging zou hebben ongewild of onbewust een ambtshalve middel zou aanvoeren bestaat er ook een aanbeveling dat het Hof nooit twee middelen of zelfs twee onderdelen van een middel samen zou beantwoorden. Er wordt immers gevreesd dat het Hof onbewust op die wijze een eigen middel zou creëren.

Verwerpen op ambtshalve opgeworpen gronden kan (de verweerder zal overigens niet altijd aanwezig zijn of een memorie neerleggen). ${ }^{6 \mathrm{r}}$

6r. Bij substitutie van motieven, zie evenwel vermeld hoofdstuk VI van het Jaarverslag Hof van Cassatie 2006 . 


\subsection{Transnationale hoven en rechtbanken}

28. Hiermede blijft het geding in cassatie ingesloten binnen enge grenzen. Transnationale of internationale hoven hebben nochtans het Hof van Cassatie hiermede in moeilijkheden gebracht.

In de zaak Petercam van I4 december 1995 en in de recente zaak 470/04 van 7 september 2006 heeft het Hof van Justitie duidelijk gemaakt dat het weren van nieuwe middelen dat mogelijk is op grond van het interne recht ${ }^{62}$ niet opgaat wanneer het gemeenschapsrecht op het spel staat. Dit betekent - geconverteerd in nationale concepten - dat het Europees gemeenschapsrecht, hoe onbelangrijk ook, moet worden beschouwd als een recht dat de openbare orde raakt en waarvan de miskenning voor het eerst voor het Hof van Cassatie kan worden aangevoerd.

Het uit artikel Io EG voortvloeiende samenwerkingsbeginsel verplicht evenwel een nationale rechter nog niet nationale procedureregels buiten toepassing te laten teneinde een in kracht van gewijsde gegane rechterlijke beslissing te onderzoeken en te vernietigen wanneer deze in strijd met het gemeenschapsrecht blijkt te zijn. ${ }^{63}$

Het nieuwe middel is wat, bij uitstek, de partijen verplicht al hun middelen uit te putten en te laten bespreken voor de feitenrechter die ook het best de feiten kan nagaan en beoordelen. Het beleid van het Hof van Justitie, gebaseerd op een eurocentrische benadering die onvoldoende rekening houdt met de specifieke taak van de opperste gerechtshoven, kan niet zonder enig voorbehoud worden aanvaard.

Het EHRM verkiest om begrijpelijke redenen de bescherming van de justitiabele te beoordelen op grond van het gehele verloop van de procedure. De subtiliteiten van een cassatieprocedure zijn het EHRM niet onbekend maar zijn in de logica van Straatsburg niet relevant. Middelen geput uit de miskenning van het EVRM zullen voor het Hof van Cassatie vaak als nieuw worden afgewezen. De reden hiertoe is niet dat de middelen niet van openbare zijn maar wel dat ook al is het middel van openbare orde het toch een onderzoek van feiten vraagt dat alleen de feitenrechter kon doen.

\section{$5 \quad$ Het gezag van de uitspraak}

\section{I Algemeen}

29. Het Hof heeft weliswaar als opdracht te waken over de eenheid van het recht maar de regel dat de rechters in de zaak die aan hun oordeel zijn onderworpen geen uitspraak mogen doen bij wege van algemene en als regel geldende beschikking is ook op hen toepasselijk. Dit geldt zelfs wanneer het Hof van Cassatie een advies uitbrengt in de prejudiciële context van de mededingingszaken. Het gezag van de beslissingen van het Hof in cassatieberoepen ${ }^{64}$ is dus geen gezag erga omnes maar geldt alleen voor de partijen.

62. Over nieuwe middelen, zie vooral Meeus, 'La notion de loi impérative et son incidence sur le procès en cassation et sur l'office du juge', RCJB I988, 498 sq.

63. H.v.J. I6 maart 2006, Kapferer, C-234/04. 
Een onderscheid moet gemaakt worden tussen het jurisprudentieel gezag en het jurisdictioneel gezag. Dit laatste dat behandeld wordt sub $§ 2$ kan juridisch relatief nauwkeurig worden gedefinieerd. Het jurisprudentieel gezag is enigszins moeilijker te vatten.

\subsection{Het jurisdictioneel gezag van een arrest van cassatie}

\subsubsection{Historisch}

30. Het Frans model is kennelijk de inspiratiebron geweest van het Nationaal congres. ${ }^{65}$ Het staat buiten kijf dat tijdens de Franse revolutie de verwijzing naar de feitenrechter, bij een vernietiging van de uitspraak, een wezenlijk deel uitmaakte van de opdracht van het Hof van Cassatie. ${ }^{66}$

In de klassieke leer mag het Hof zijn eigen beslissing niet in de plaats stellen van die van de appelrechter en het is de beslissing van de feitenrechter die een uitvoerbare titel moet opleveren. ${ }^{67}$

Die leer die door een groot aantal procureurs generaal in de voorbije eeuw werd uiteengezet en nog aanhangers telt, is niet onjuist maar een duidelijke evolutie op dat punt kan worden waargenomen. Het model van de Europese opperste gerechtshoven is minder dat van het klassieke Franse Hof van cassatie dan wel een soort tussenmodel dat zich bevindt tussen revisie en cassatie en uiteraard het nadeel biedt van een minder duidelijk beeld aangezien elementen uit de twee systemen worden gecombineerd. Zelfs het Franse Hof van Cassatie evolueert naar een model zonder systematische verwijzing en zonder een tweede cassatie.

\subsubsection{Gezag bij verwerping}

3I. Een arrest dat een cassatieberoep verwerpt en het geding beëindigt heeft wel gezag van gewijsde op de beslechte punten die aan het Hof werden voorgelegd. Aldus is de juridische kwalificatie gegeven door de appelrechter en door het Hof beaamd, aan een rechtsverhouding, bindend.

Zoals Boré het laat opmerken kan een arrest van het Hof ook het gezag van het gewijsde van het arrest waartegen cassatieberoep werd ingesteld wijzigen. Dit geldt bv wanneer het Hof een substitutie van motieven doorvoert. De redenen van de appelrechters zullen dus niet meer dienstig zijn voor de appreciatie van de draagwijdte van de beslissing van de appelrechters. ${ }^{68}$

64. Dit is volledig anders bij de bijzondere bevoegdheden van het Hof, onder meer in de tuchtzaken en bij de 'administratieve' nietigheidsberoepen van artikel 6ro Gerechtelijk Wetboek.

65. Zie hiervoor C. Scheyven, Traité pratique des pourvois en cassation, $2^{\mathrm{e}}$ uitg. Bruylant-Christophe, $\mathrm{I}_{8} 8_{5}$, p. 25 tot 27; C. Storck, 'Le renvoi au juge du fond dans la procédure en cassation en matière civile', in Imperat lex, cit. p. 209-210; P. Leclercq, De la cour de cassation, Openingsrede I oktober 1925.

66. Zie hierover E.Chenon, Origines, conditions et effets de la cassation, Parijs, Larose en Forcel, I882, nr. 22, p. 65: 'désormais, le principe essentiel que la juridiction de cassation ne doit jamais connaître du fond des affaires devrait enfin être respecté'.

67. Zie nochtans voor de dwangsom, Cass. 6 mei 2005, Co30402, www.cass.be. De dwangsom kan slechts verbeurd worden na betekening van het cassatiearrest.

68. Zie Cass.fr. 7 december 1976, Gaz.Pal., I977,I pan. p.90; Boré, op.cit. nr. I24.3I. 
Meer betwistbaar is het gevolg van een beslissing van het Hof van Cassatie dat een reden van de appelrechters overtollig is. Volgens Boré is dit ook een geval waarin het arrest van het Hof van Cassatie een invloed uitoefent op de inhoud van het arrest van de appelrechters. ${ }^{69}$

De Franse rechtspraak aanvaardt - en eenzelfde oplossing zou ook gelden in België - dat het arrest van het Hof van Cassatie bindend is in verband met de uitlegging van de bestreden beslissing (uiteraard, in zoverre die beslissing wordt bestreden). ${ }^{70} \mathrm{Er}$ anders over beslissen zou leiden tot een oneindige reeks van mogelijke cassatieberoepen.

Een aanwijzing in die richting is de praktijk die nu bestaat sinds enkele jaren in het Hof van Cassatie om in complexe zaken de feiten weer te geven. Wanneer het Hof vaststelt dat de feiten die het weergeeft (in een deel II: rubriek De feiten) blijken uit het bestreden arrest, dan is die weergave ook bekleed met gezag. Wanneer het Hof van Cassatie benadrukt dat het enige afstand neemt van die weergave, dan laat het Hof dat kennen door de vermelding dat 'uit het verzoekschrift blijkt dat...'

\subsubsection{Gezag bij een arrest van vernietiging}

32. In beginsel wordt cassatie uitgesproken in civiele zaken met verwijzing. De basis voor die regel wordt meestal gevonden in artikel I47 van de Grondwet ('er bestaat voor geheel België een Hof van Cassatie. Dit Hof treedt niet in de beoordeling zelf van de zaken'). Het Hof kan volgens de klassieke leer niet oordelen over de zaak zelf en zijn oordeel in de plaats stellen van de voorgelegde beslissing. ${ }^{7 \mathrm{I}}$

De vernietigingsarresten hebben dan ook in beginsel geen gezag van het gewijsde tenzij zij gewezen worden in verenigde kamers na een tweede verwijzing waarop het Hof vernietigt op dezelfde gronden. ${ }^{72}$

De rechter zal dus verwijzen na cassatie naar een andere rechter. Dit staat in schril contrast met wat gebeurt bij de appelrechters. Bij de totstandkoming van het Gerechtelijk Wetboek in 1967 en in de daaropvolgende jaren was het besef levendig dat misbruiken bestonden als gevolg van de onbeperkte appellabiliteit van vonnissen. De verruimde devolutieve kracht van het hoger beroep laat aan de appelrechter toe de volledige zaak tot zich te trekken ook al was het geschil nog niet volledig beëindigd voor de eerste rechter. De uitzonderingen op de devolutieve kracht worden doorgaans beperkend uitgelegd.

33. De gevallen waarin er geen verwijzing gebeurt, in civiele zaken, zijn uitzonderlijk. Het zijn gevallen waarin niets meer te beslissen valt en het niet past dat een verwijzingsrechter nog een nadere beslissing zou nemen.

69. J. Boré en L. Boré, op.cit. nr. I24.I3.

70. Cass.fr. 24 oktober I92I, DP I925, I, 46.

7I. Hayoit de Termicourt, 'Propos sur l'article 95 de la Constitution'. Rede uitgesproken op I5 september I954; F. Dumon, Com. Ger. sub artikel IIIo.

72. Cass. I februari i99I, AC I99I, nr. 294. 
In strafzaken - die buiten deze bespreking vallen - komt dit vaak voor op grond van een expliciete wetsbepaling (artikel 429 W.Sv), wat uitwijst dat de regel van de verplichte verwijzing ook niet zo fundamenteel is.

In civiele zaken is de historische en nog binnen zekere grenzen geldende regel dat verwijzing verplicht is en het arrest van cassatie geen gezag van het gewijsde heeft. De rechter naar wie na cassatie verwezen wordt is zelfs niet gebonden door de uitspraak van het Hof maar mag een andere visie hebben over de zaak, en het is alleen na een tweede cassatieberoep dat de rechter naar wie verwezen wordt gebonden is door de rechtsoverwegingen van het Hof. Maar ook in dat geval is een verwijzing verplichtend.

Dat klassiek schema staat onder vuur om een veelheid van redenen. De kritiek tegen dat schema is niet recent en het is opvallend dat in een periode waarin het Hof van Cassatie nog vrij uitvoerig motiveerde (in de XIXe eeuw) heel wat arresten afweken van deze leer. ${ }^{73}$ Dit gold in het bijzonder wanneer het Hof vernietigde op grond dat de appelrechter ten onrechte had vastgesteld dat er geen verjaring bereikt was, dat de oorspronkelijke dagvaarding niet nietig was, dat het hoger beroep ontvankelijk was, dat de rechter bevoegd was of gehandeld had zonder overschrijding van macht. Die leer werd bijgevallen door Scheyven en zelfs door procureur generaal Mesdach de ter Kiele, ${ }^{74}$ maar werd later (voorlopig?)verlaten vanaf een arrest van 4 mei rgi6.75

34. De praktijk heeft opnieuw stilaan een aantal beperkingen ingevoerd op de regel die niet meer zo stringent is, ofschoon de Grondwet nog altijd de basis van die leer vermeldt met name dat het Hof niet in de beoordeling van de zaak zelf treedt.

Die beperkingen op de plicht de eindbeoordeling te laten doen door de rechter naar wie verwezen wordt zijn thans zichtbaar op drie vlakken: ofwel wordt er niet verwezen, ofwel wordt er verwezen naar een rechter op een wijze die in feite neerkomt op een beoordeling door het Hof van Cassatie, ofwel wordt er verwezen op bindende wijze naar de feitenrechter.

Cassatie zonder verwijzing komt zeer zelden voor. In cassatieberoepen tegen de beslissingen van de tuchtraden van beroep wordt aangenomen dat de tuchtraden van beroep gebonden zij door de beslissing van verwijzing. Een cassatie zonder verwijzing zou denkbaar zijn omdat in die zaken de raden van beroep zich naar de beslissing van het Hof van Cassatie moeten voegen betreffende het door het Hof beslechte rechtspunt. ${ }^{76}$

Bij vernietiging in het belang van de wet (artikel ro89 Ger.W.) wordt cassatie uitgesproken zonder verwijzing. Een samenspraak met een verwijzingsrechter is hier vanzelfsprekend uitgesloten.

73. Zie de bijzonder interessante commentaar en de bronnen vermeld door C.Storck, in zijn uitstekende studie 'Le renvoi au juge du fond dans la procédure en cassation en matière civile' in Imperat lex, cit., p. 213.

74. Zie hierover Scheyven, 'Des cassations sans renvoi', Belg.Jud. I9I3, kol. 69r.

75. Pas.igi6, I, 9i.

76. Zie bijv. Cass. 2 februari 1978, AC $1978,658$. 
Heeft een dergelijk arrest dan wel een gezag van het gewijsde en heeft het een andere dan een doctrinale draagwijdte? In zekere zin wel doordat de rechter wiens beslissing vernietigd wordt in het belang van de wet en aan wie zou gevraagd worden zijn beslissing - die blijft bestaan - uit te leggen, niet bij wege van uitlegging zou mogen de redenen betwisten die het Hof van Cassatie heeft gebruikt voor de vernietiging. Dit is dus een vrij beperkte jurisdictionele draagwijdte.

35. Wanneer het Hof van Cassatie vernietigt met verwijzing, is de rechter naar wie verwezen wordt in beginsel vrij opnieuw de zaak volledig te beoordelen zoals hij het wil.

Hierop bestaan nochtans vrij veel uitzonderingen.

Vooreerst, zoals reeds gezegd werd, moeten de raden van beroep van de vrije beroepen zich onmiddellijk voegen naar de uitspraak van het Hof van Cassatie.

Vervolgens is er een merkwaardige kentering geweest in verband met de bevoegdheid. Het Hof heeft aangenomen dat wanneer het casseert op een grond van bevoegdheid het de zaak verwijst naar de rechter die volgens het Hof de bevoegde rechter is. Deze rechter naar wie verwezen wordt, kan niet meer de hem toegewezen opdracht weigeren. Het Hof is tot die (pragmatische) conclusie gekomen op grond van een zeer ruime uitlegging van de artikelen 642,643 en 66 o van het Gerechtelijk Wetboek. 77

De principiële vrijheid in de andere zaken blijft dus bestaan, al wordt vastgesteld dat a. de partijen meestal een dading sluiten na het cassatiearrest; b. de feitenrechters zich in de andere gevallen praktisch altijd neerleggen bij de uitspraak van cassatie.

Wanneer de rechter naar wie verwezen wordt in opstand komt tegen het arrest van cassatie, is uiteraard een nieuw cassatieberoep denkbaar. De rechter naar wie de zaak dan verwezen wordt moet zich gedragen naar wat eerst werd beslist.

Het recht op rebellie kan eventueel aantrekkelijk lijken maar er wordt dus zeer weinig gebruik van gemaakt. Het hoeft er in feite niet te zijn: als de feitenrechters het oneens zijn met het beleid zal er meestal wel op korte termijn een nieuwe gelegenheid zijn voor de feitenrechter om opnieuw de cassatierechtspraak te testen.

Een beperking van de mogelijkheid van een tweede cassatieberoep zoals het geval is in de meeste andere landen zou hier welkom zijn. Het zou op dat ogenblik ook toelaten meer zaken definitief af te handelen zonder verwijzing (bijv. wanneer het Hof van Cassatie tot de vaststelling komt dat een zaak verjaard was).

Zoals door Rogier De Corte wordt vastgesteld kan de regel van de niet-bindende kracht van de uitspraken in redelijkheid niet meer worden verantwoord en zou een bindende kracht een bijdrage kunnen zijn in een vereenvoudiging van de perceptie van de taak van het Hof. ${ }^{78}$

77. Zie Cass., 22 september 2005, www.cass.be; in Frankrijk is deze evolutie verworven langs wetgevende weg.

78. R. De Corte, op.cit., rn. 43 . 


\subsection{Jurisprudentieel gezag van het arrest}

36. Het jurisprudentieel gezag van de arresten van het Hof is vrij hoog. De redenen hiertoe zijn veelvoudig. De rechters wensen uiteraard dat hun beslissingen zoveel mogelijk aan de partijen rechtszekerheid bieden en dus niet zouden bestreden worden.

Daarenboven zijn de arresten van het Hof vrij goed gekend door de praktijk. De gegevensbank Juridat die toelaat de arresten (en desgevallend de conclusie van het openbaar ministerie) te lezen enkele dagen na de uitspraak is een belangrijke factor van eenmaking van het recht.

Dit betekent niet dat de feitenrechters altijd de leer van het Hof volgen en het is niet uitzonderlijk dat een feitenrechter desbewust afwijkt van de precedenten. Dit hoort overigens bij een goede rechtsbedeling.

Een onaangename evolutie heeft zich voorgedaan de laatste jaren doordat enkele feitenrechters gepoogd hebben het Grondwettelijk Hof ertoe te brengen vaststaande leer van het Hof van Cassatie te doen wankelen. ${ }^{79}$ Het Grondwettelijk Hof is bevoegd om een strijdigheid tussen de Grondwet en inzonderheid het gelijkheidsbeginsel vast te stellen. Welnu elke wet, elk decreet, houdt een mate van ongelijkheid in, juist omdat het iets reguleert. In de mate het Grondwettelijk Hof een uitlegging van de wet of het decreet aanhield die afweek van die welke het Hof van Cassatie oplegde, was de verwarring het eindresultaat van die strategie. Het Grondwettelijk Hof heeft de twee laatste jaren veel belang gehecht aan dit aspect zodat het aantal conflicten vrij beperkt is ... en de wetgever ook minder moet ingrijpen.

\section{Prejudiciële vragen}

\section{I Prejudiciële procedure in mededingingszaken}

37. Krachtens de artikelen 72 en 73 van het Koninklijk Besluit van 15 september 2006 houdende coördinatie van de wet van ro juni 2006 over de bescherming van de economische mededinging en de wet van Io juni 2006 tot oprichting van een raad voor de mededinging kan het Hof prejudiciële vragen afhandelen die betrekking hebben op de wet op de economische mededinging.

De procedure die dit regelt is zeer summier in de wet aangewezen in artikel 73 van die wet.

De wettekst c.q. de richtlijnen die het Hof van Cassatie hanteert, zijn de volgende:

§ I. Wanneer de oplossing van een geschil afhangt van de interpretatie van deze wet, kan het gerecht waarbij de zaak aanhangig is gemaakt, met inbegrip van de Raad voor

79. Enkele feitenrechters hebben eveneens gepoogd het gezag van het Grondwettelijk Hof te doen wankelen door de tegenovergestelde poging waarvoor steun gezocht werd in cassatierechtspraak: de arresten van het Grondwettelijk Hof op prejudiciële verwijzing hebben geen gelding erga omnes, wat afwijkingen toelaat. 
de Mededinging, de uitspraak uitstellen en een prejudiciële vraag stellen aan het Hof van Cassatie.

De beslissing om een prejudiciële vraag te stellen aan het Hof van Cassatie schorst de termijnen en de procedure voor de rechtbank die de vraag stelt vanaf de dag waarop de beslissing werd genomen tot de dag waarop het gerecht waarbij de zaak aanhangig is gemaakt het antwoord van het Hof van Cassatie ontvangt.

Tegen de beslissing van de rechter om een prejudiciële vraag te stellen of een dergelijke vraag niet te stellen kan geen enkel rechtsmiddel worden aangewend.

$\S 2$. De griffier van het Hof van Cassatie stelt de partijen, de Raad voor de Mededinging, de minister en, in het geval van toepassing van de artikelen 8I en 82 van het Verdrag tot oprichting van de Europese Gemeenschap, de Europese Commissie onverwijld in kennis van de prejudiciële vraag.

De griffier van het Hof van Cassatie nodigt de partijen, de minister en de Europese Commissie uit om hun schriftelijke opmerkingen over te zenden, op straffe van onontvankelijkheid, binnen een maand na de kennisgeving van de prejudiciële vraag.

Praktisch gezien krijgt elke partij één maand en acht dagen om het dossier in te zien zonder verplaatsing. Het is nochtans mogelijk dat elektronisch van op afstand toegang zou worden verleend zodra het dossier gedigitaliseerd zal zijn (dus na de inwerkingtreding van de desbetreffende bepaling van de wet van io juli 2006). Elke partij krijgt ook één maand en acht dagen om te vragen gehoord te worden.

$\S 3$. Deze laatsten kunnen elk vragen om gehoord te worden en het proceduredossier ter plaatse raadplegen of vragen dat hen een afschrift wordt toegezonden. Wanneer de prejudiciële vraag gesteld wordt door de Raad voor de Mededinging, wordt de auditeur, die voor de Raad voor de Mededinging de zaak onderzoekt binnen het kader waarvan de vraag wordt gesteld, uitgenodigd door de griffier bij het Hof van Cassatie om zijn opmerkingen in te dienen volgens de nadere regels bedoeld in $\S 2$, tweede lid.

Het Hof kan de prejudiciële vraag herformuleren. Het Hof neemt een met redenen omklede beslissing. Het Hof doet uitspraak met voorrang boven alle andere zaken.

Wat gebeurt er wanneer er geen (tijdige) aanvraag is om gehoord te worden?

De procedure verloopt schriftelijk. Het openbaar ministerie krijgt ook de gelegenheid om schriftelijk een conclusie te nemen, zodat de procedure op dat punt niet zal afwijken van het gemene recht. De conclusie van het openbaar ministerie wordt overhandigd aan de Raad voor de mededinging, aan de partijen, aan de Minister van Economische zaken, en uiteraard ook aan de Europese Commissie. De partijen worden uitgenodigd om schriftelijk te reageren binnen een termijn van vijftien dagen op de conclusie van het openbaar ministerie. Het arrest wordt gewezen uiterlijk vijf maanden nadat de aanvraag is binnengekomen in het Hof van Cassatie.

Wanneer er wel een tijdige vraag is, wordt na verloop van de periode van een maand en acht dagen, een hearing gehouden van de personen die gevraagd hebben te worden gehoord (de griffie wenst niet dat volledig Brabant zou worden gehoord). De griffier verwittigt de partijen van plaats en uur van verschijning. 
Het openbaar ministerie zal ook concluderen - er is geen bijzondere reden om hem niet te horen - binnen een termijn van twee weken na de hearing. De conclusie zal normaal ter griffie worden neergelegd en doorgestuurd worden aan de partijen. De partijen beschikken over twee weken na de vermoede ontvangst van de conclusie om schriftelijke opmerkingen te maken over die conclusie.

Na afloop van de termijn wordt de prejudiciële beslissing gewezen. De einduitspraak zal op die wijze uiterlijk plaats grijpen vijf maand nadat de vraag is binnengekomen.

Die aanvullingen op de tekst van de wet waren nodig om op voorhand de partijen in te lichten over de wijze waarop zij hun opmerkingen kunnen indienen: dit zijn eveneens de vereisten van een eerlijk proces en van de gelijkheid der partijen. Deze richtlijnen zullen gepubliceerd worden in het jaarverslag 2007 van het Hof en op de website van het Hof (www.cass.be).

Het recht op tegenspraak wordt aldus binnen bepaalde grenzen gehandhaafd. De nood om snel een prejudicieel antwoord te geven kan verplichten snel te werk te gaan en de partijen niet onbeperkt toe te laten in de prejudiciële procedure tussen te komen of die procedure te vertragen. Het gaat eerst en vooral om een dialoog met de rechter die verwezen heeft en de partijen kunnen nog altijd later voor die rechter hun standpunt laten gelden.

\subsection{Prejudiciële procedures (Hof van Justitie en Beneluxgerechtshof)}

38. Het Hof van Cassatie kan ook zelf prejudiciële vragen stellen en is zelfs hiertoe verplicht als gerecht in laatste instantie zowel naar het Beneluxgerechtof, het Grondwettelijk Hof (zie sub 6.3) als naar het Europees Hof van Justitie.

Die verplichting berust op het besef dat de betere wijze om de rechtspraken te harmoniseren of te controleren is door het sluitstuk van de nationale rechterlijke orden te verplichten zich te onderwerpen aan de rechtspraak van de genoemde externe gerechtelijke instellingen.

Het lag voor de hand dat dit niet probleemloos kon verlopen omdat het concept van de prejudiciële vraag op een dubbele manier indruist tegen de basisreacties van het Hof van Cassatie: het Hof moet een zaak uit handen geven, met alle nadelen van dien, en het moet de zaken uit handen geven aan een orgaan buiten de rechterlijke macht en dat politieke verantwoordelijkheden en reflexen heeft.

39. Krachtens artikel 234 EG Verdrag is het Hof van Justitie bevoegd, bij wijze van prejudiciële beslissing, een uitspraak te doen met name over de uitlegging van dit Verdrag en over de geldigheid en de uitlegging van de handelingen van de instellingen van de Gemeenschap. Artikel 6 van het Verdrag van 3i maart I 965 betreffende de instelling en het statuut van een Benelux-Gerechtshof ${ }^{80}$ kent de bevoegdheid toe aan

8o. B.S. II december 1973 . 
het Beneluxhof om kennis te nemen van vragen betreffende de uitleg van rechtsregels die gemeen zijn aan de Beneluxlanden.De prejudiciële procedure is een vorm van integratie of eenmaking in onvolkomen organisaties zoals de Europese Unie of de Benelux-unie. Doordat zij los staat van de gewone rechterlijke procedure is zij enigszins een anomalie die de rechter - die een zaak uit handen moet geven - eerst zal doen steigeren maar waaraan de rechter zich voor het algemeen belang zal onderwerpen. De internationale wetgever was duidelijk hiervan bewust en heeft de verplichting te verwijzen, beperkt tot de opperste gerechtshoven. ${ }^{8 \mathrm{I}}$ Het Hof van Justitie heeft wel een uitzondering gesteld op de in artikel 234 EG Verdrag gestelde regel dat de rechterlijke instantie waarvan de beslissingen volgens het nationale recht vatbaar zijn voor hoger beroep, niet verplicht is te verwijzen naar het Hof van Justitie. Als die rechterlijke instantie meent dat een opgeworpen vraag van ongeldigheid van een handeling van een gemeenschapsinstelling gegrond is, dient zij de behandeling te schorsen en bij prejudiciële verwijzing het Hof te verzoeken om beoordeling van de geldigheid. ${ }^{82}$ De nationale rechter is immers niet bevoegd om handelingen van gemeenschapsinstellingen ongeldig te verklaren. De reden is volgens het Hof van Justitie te zoeken in de noodzakelijke samenhang van het door het EEG-Verdrag ingevoerde stelsel van rechtsbescherming. ${ }^{83}$

De verplichting te verwijzen voor de nationale rechterlijke instantie waarvan de beslissingen volgens het nationale recht niet vatbaar zijn voor hoger beroep, is in zekere mate verzwakt, hetzij door de Verdragsteksten ${ }^{84}$ zelf (in het Benelux-geval), hetzij door de rechtspraak ${ }^{85}$ (van het Hof van Justitie). Bij een 'acte clair ${ }^{86}$ of een 'acte éclairé 87 moet immers geen vraag gesteld worden. Ook als het Hof vaststelt dat de voor hem opgeworpen vraag niet relevant is, dient hij die niet te stellen aan het Hof van Justitie. Dit zijn echter alleen maar specifieke uitzonderingen op een principiële verplichting.

Daaruit volgt dat het Hof van Cassatie geen vraag stelt aan het Hof van Justitie als een zaak met dezelfde vraag als aan hem voorgelegd, reeds hangend is bij het Hof van Justitie. Dit is tevens een manier om tijd te winnen.

In dat wettelijk kader moet de rechter immers ook een andere regel naleven, dit is, de eerbiediging van de redelijke termijn. Het stellen van een prejudiciële vraag kan in bepaalde omstandigheden haaks staan op de verplichting voor de rechter de eerlijke termijn na te leven. Dit is wellicht niet een probleem van het EVRM - het EHRM erkent dat de prejudiciële vraag kan gelden als een excuus voor de trage gang van

8I. Het Hof van Justitie heeft, met een zeer ver gaande interpretatie, de verplichting opgelegd aan alle rechtsinstanties wanneer de geldigheid van een Europese (secundaire) norm op het spel staat.

82. H.v.J., Io januari 2006, International Air Transport Association, C-344/04, Jur. 2006, I-403.

83. H.v.J., 22 oktober I987, Foto-Frost, 314/85, Jur. I987, 4I99 en S.E.W., I988, 638.

84. Artikel 6.4 van het Verdrag van 3 I maart I $_{965}$ betreffende de instelling en het statuut van een Benelux-Gerechtshof.

85. Zie o.a. H.v.J., I5 september 2005, Intermodal Transports, C-495/03, Jur. 2005, I-8I5I; 6 oktober I982, CILFIT, 283/8I, Jur. I982, 34I5.

86. De juiste toepassing van het gemeenschapsrecht is zo evident, dat redelijkerwijze geen ruimte voor twijfel kan bestaan. Bij de vraag of een acte clair zich voordoet, wordt rekening gehouden met de eigen kenmerken van het gemeenschapsrecht, de bijzondere moeilijkheden bij de uitlegging ervan en het gevaar van uiteenlopende rechtspraak binnen de Gemeenschap.

87. De betrokken gemeenschapsbepaling is reeds door het Hof van Justitie uitgelegd. 
zaken - maar betekent wel een probleem voor de justitiabele die geconfronteerd wordt met onaanvaardbaar lange wachttijden. Indien redenen van spoedeisendheid voorhanden zijn waardoor de zaak geen uitstel gedoogt, is het mogelijk voor de nationale rechter geen vraag te stellen aan het Beneluxhof. 88

De verwijzing mag alleen gebeuren gelet op de dwingende eisen van de redelijke termijn en ook van het recht niet te worden onttrokken aan de rechter die de Grondwet aan de justitiabele toewijst, wanneer zij nodig is of door de wet wordt opgelegd. Zij moet ook gebeuren in omstandigheden die de verlenging van de procedure reduceert tot aanvaardbare proporties.

De idee is verdedigbaar dat, om het proces te versnellen, wat een verplichting is van het EVRM, ${ }^{89}$ de rechter al een antwoord suggereert aan het Hof naar waar verwezen wordt, of tenminste reeds een aantal vragen zelf oplost van louter intern recht, zodat het Hof van Justitie en het Benelux-Gerechtshof een nauwkeurig gepreciseerde vraag krijgen waarvan de beantwoording in het concreet geschil evident nuttig zal zijn.

Het Hof van Cassatie waakt erover dat het Hof van Justitie in het bijzonder een volledig feitenrelaas ontvangt in het arrest zelf ${ }^{\circ}$ en dat alle middelen die los staan van de vraag van Europees of grondwettelijk recht reeds op voorhand zijn beslecht.

40. De concrete wijze waarop een prejudiciële vraag aan het Hof van Justitie of aan het Beneluxgerechtshof wordt doorgezonden, wordt in beperkte mate door het Hof van Justitie of het Beneluxgerechtshof bepaald. Wat na de verzending van het dossier gebeurt en vooral wat er gebeurt eens de prejudiciële beslissing is gewezen, wordt helemaal niet bepaald in de Belgische wetgeving.

De praktijk op het Hof van Cassatie is de volgende. Nadat het Hof van Cassatie kennis heeft gekregen van het antwoord, vraagt de griffier van de kamer of de partijen nog een bijkomende noot willen neerleggen. De griffier krijgt instructies van de bevoegde afdelingsvoorzitter om een maximumtermijn toe te kennen (meestal één maand). Nadat de rapporteur een concept gemaakt heeft van eindarrest, stelt de afdelingsvoorzitter de zaak vast voor een dag waarop de zaak opnieuw kan worden gehoord en waarop het openbaar ministerie een aanvullende conclusie kan nemen. Na de conclusie te hebben aanhoord kunnen de partijen daarenboven nog een bijkomende noot neerleggen over wat gezegd is geweest door het openbaar ministerie.

Die praktijk kan verrassen, omdat in een prejudiciële vraag alleen een dialoog wordt gevoerd tussen de verwijzingsrechter en het Beneluxgerechtshof of Hof van Justitie. De partijen blijven in beginsel hieraan vreemd, tenzij in bepaalde enge grenzen. Maar die dialoog is in zekere mate een juridische fictie en gelet op het nieuwe feit van het antwoord, is het noodzakelijk voor een eerlijk proces dat de partijen en het openbaar ministerie opnieuw de kans zouden krijgen te worden gehoord.

88. Artikel 6.4.2 van het Verdrag van 31 maart 1965 betreffende de instelling en het statuut van een Benelux-Gerechtshof.

89. Cfr. EHRM I2 juni 200I, Brochu t.Frankrijk, D.2002, Somm. 689, noot Fricero.

9o. Dit is belangrijk, omdat de stukken van het dossier in Luxemburg niet zullen worden vertaald. 


\subsection{Prejudiciële procedures - Grondwettelijk Hof}

4I. Artikel 26 van de bijzondere wet op het Grondwettelijk Hof houdt binnen bepaalde grenzen een verplichte verwijzing in naar het Grondwettelijk Hof voor de beslechting van de conflicten tussen wet, decreet of Ordonnantie en Grondwet. De regels voor de hoogste rechtscolleges zijn strenger dan die welke gelden voor de andere rechtscolleges. Die verplichting is ingegeven door een bepaalde mate van wantrouwen van de wetgever die twijfelde aan de bereidheid van de hoogste rechtscolleges om prejudiciële vragen te stellen aan het Grondwettelijk Hof met alle risico's van dien voor het 'monopolie' van het Grondwettelijk Hof om wetskrachtige normen aan de Grondwet te toetsen. ${ }^{9 \mathrm{I}}$ Die discriminerende behandeling wordt door velen bekritiseerd ${ }^{92}$ maar zij bestaat en is niet zo ongewoon zoals blijkt uit de voorbeelden van het Europese en Benelux-recht.

Een a priori beperking van de bevoegdheid van het Grondwettelijk Hof vinden wij nochtans in SIbis van artikel 26 van de bijzondere wet, ingevoegd bij wet van 9 maart 2003: 'Van het toepassingsgebied van dit artikel worden uitgesloten de wetten, de decreten en de in artikel I 34 van de Grondwet bedoelde regels waardoor een constituerend verdrag betreffende de Europese Unie of het Verdrag van 4 november 1950 tot bescherming van de rechten van de mens en de fundamentele vrijheden of een Aanvullend protocol instemming verkrijgt'. Dit wijst er al op dat voor die verdragsteksten of internationale regels een verstandige uitlegging geboden is wat betreft de prejudiciële bevoegdheid van het Grondwettelijk Hof.93

De bevoegdheid van het Grondwettelijk Hof [m.b.t. het EVRM althans] om het EVRM te betrekken in de beoordeling is niet betwistbaar. ${ }^{94}$ In bepaalde gevallen kon een samenloop van beschermingen ontstaan doordat eenzelfde fundamenteel recht wordt beschermd zowel door de Grondwet als door het Verdrag. Die samenloop is niet altijd vanzelfsprekend. Het Grondwettelijk Hof oordeelt dat de schending van een grondrecht automatisch de schending inhoudt van het gelijkheidsbeginsel, maar dit is een gewaagde stelling, zoals overtuigend gedemonstreerd door H. Simo-

9I. M. Van Damme, 'Het stellen van prejudiciële vragen aan het Arbitragehof door het Hof van Cassatie en de Raad van State', in: Imperat lex - Liber Amicorum Pierre Marchal, Brussel, Larcier, 2003, I43. Van Damme pleit voor de opheffing van de door hem als onevenredig aangevoelde verplichting tot verwijzing.

92. Zie o.m. K.Rimanque, 'Het labyrint van de rechtsbescherming tegen ongeldige rechtsregels', in A. Arts, I. Verougstraete, R. Andersen e.a., Het Arbitragehof, de Rechterlijke macht en de Raad van State, Die Keure 2006, 374 .

93. Over de draagwijdte van deze beperking, zie Th. Bombois, 'la restriction de compétences de la Cour d'arbitrage à l'égard des traités internationaux', in: A. Rasson-Roland, D. Renders, en M.Verdussen, La Cour d'arbitrage vingt ans après-Analyse des dernières réformes, Bruylant 2004, p. I50I77.

94. Voor het EG-recht is dat nog anders. De rechtspraak van het Hof van Justitie vertoont meer dan een spoor van wantrouwen tegenover de Grondwettelijke Hoven: in deze materies zijn prejudiciële vragen aan het Grondwettelijk Hof bijna zeker uitgesloten. Het Hof van Cassatie heeft in die gedachtengang in een arrest van 4 november 1996 (over discriminatie tussen man en vrouw bij de pensioenberekening) als het ware vanzelfsprekend eerst de vraag gesteld aan het EG-Hof en dan, na ontvangst van het antwoord van het Hof van Justitie waaruit nuttige elementen konden geput worden voor een uitlegging van de nationale wet, beslist dat er geen reden was om nog een vraag te stellen aan het Arbitragehof (Cass. 8 maart 1999). 
nart. ${ }^{95}$ Maar samenloop is vaak present en in het bijzonder, tussen artikel 6 EVRM en de artikelen 13 en 23 Grondwet.

Het recht op een eerlijk proces dat door het EVRM wordt gewaarborgd verplicht het Hof van Cassatie na te gaan op welke wijze de inhoud van dat recht het best wordt verzekerd. De effectiviteit van de bescherming is nochtans niet het enige criterium dat het Hof van Cassatie moet hanteren: het algemeen belang, de rechtszekerheid en de goede rechtsbedeling spelen ook een belangrijke rol. Ook de redelijke termijn voor de behandeling van de zaak is een parameter: een prejudiciële verwijzing die leidt tot de overschrijding van de redelijke termijn moet worden vermeden.

Geen enkele wetsbepaling of grondwetsbepaling legt duidelijk uit hoe de opperste rechter (Hof van Cassatie of Raad van State), voor wie een dergelijke samenloop van beschermingen wordt opgeworpen, moet ageren. ${ }^{96}$ Een eenvoudige oplossing kan worden gevonden in een monistische benadering, die een uitdrukking vindt in het beginsel van het primaat van bepalingen met rechtstreekse werking van het internationaal recht (incl. het gemeenschapsrecht) op beginselen van nationaal recht. Dit beginsel, dat geen algemeen rechtsbeginsel is met grondwettelijke waarde maar veeleer zijn rechtstreekse oorsprong vindt in het internationaal recht, is voor het eerst erkend door het Hof van Cassatie bij het arrest van 27 mei I97I. Een wijziging van de Grondwet die de hiërarchie anders bepaalt, zou dan ook door de rechter terzijde worden gelaten. 97

Als de rechter het geschil oplost op grond van de toetsing van de wet aan het Verdrag - en dus niet raakt aan de Grondwet die in zijn redenering niet nodig is voor de oplossing van het geschil - hoeft hij de zaak niet prejudicieel te verwijzen naar het Grondwettelijk Hof. Als nog iets te beslissen valt, na een aanvankelijke toetsing van de wet aan het Verdrag, zou hij de zaak voor het saldo dat nog te berechten valt kunnen of moeten verwijzen naar het Grondwettelijk Hof (dat op dat ogenblik in werkelijkheid nauwelijks nog iets te beslissen heeft).

Die simpele oplossing als zij blindelings wordt doorgevoerd, is wellicht niet formeel in strijd met het Verdrag, de wet of de Grondwet - en is zelfs een verplichte oplossing voor het Gemeenschapsrecht op grond van de Simmenthaldoctrine maar een automatische toepassing lijkt niet opportuun omdat zij ertoe leidt, gelet op het grote aantal gevallen van samenloop van bescherming van fundamentele rechten, naar een aanzienlijke verschraling van de taak van het Grondwettelijk Hof in verband met fundamentele rechten. ${ }^{98}$ Die verschraling zou te betreuren zijn aangezien het Grondwettelijk Hof door prejudiciële antwoorden te geven in deze materie de kans krijgt om de Grondwet met groot gezag (dit is iets minder diffuus dan het

95. H. Simonart, 'Les aspérités d'un contrôle de constitutionnalité polymorphe', in Het Arbitragehof, de rechterlijke macht en de Raad van State, p. 393 (Die Keure 2006).

96. Een wetsvoorstel van Senator Van den Berghe probeerde hiervoor een oplossing te vinden in het kielzog van het symposium gehouden tussen de drie opperste rechtscolleges maar die oplossing vond geen steun bij bepaalde betrokken rechtsinstanties.

97. A. Bossuyt, 'Algemene rechtsbeginselen in de rechtspraak van het Hof van Cassatie', T.P.R. 2004, (I589) I6oI.

98. Dit klemt des te meer nu krachtens de leer van het arrest Simmenthal van het Hof van Justitie EG in de zaak 106/77 de nationale rechters de 'omweg' van een grondwettelijk hof niet mogen maken in de gemeenschapsmateries. Dit is van cruciaal belang gelet op het feit dat de mensenrechten meer en meer deel uitmaken van het gemeenschapsrecht. 
Hof van Cassatie) uit te leggen en die uitlegging te doen aansluiten bij de lering van het EHRM.

Mechanische oplossingen zouden het nut van een grondwettelijk hof voor een deel doen verdwijnen. Pragmatische oplossingen zijn best mogelijk en laten toe aan het Hof van Cassatie en de Raad van State een verwijzingsbeleid uit te stippelen. Die pragmatische oplossingen worden in feite opgelegd door de eisen van een eerlijk proces.

Artikel 26 van de wet van 26 januari 1989 bevat wel een principiële verplichting tot verwijzing door het Hof van Cassatie en de Raad van State in het geval van een aangevoerde schending van de Grondwet door de wet of decreet. De toepassing van dit artikel en zijn uitlegging in samenhang met andere bepalingen, hebben bewezen dat een grote flexibiliteit mogelijk was en dat een goed op elkaar afgestemde praktijk mogelijk was, waarbij ieder zijn rol vervult.

In geval van een dergelijke samenloop is het van belang dat het Grondwettelijk Hof de kans zou krijgen een gezaghebbende interpretatie te geven waarbij de interne grondwettelijke orde en de internationale orde met elkaar kunnen worden verzoend. ${ }^{99}$ Het Grondwettelijk Hof oordeelt met een iets minder diffuse toetsing dan het Hof van Cassatie dat ook niet echt diffuus oordeelt maar toch iets meer dan het Grondwettelijk Hof.

In dit geval zou de opperste rechter die heeft vastgesteld, zonder zulks noodzakelijk uit te drukken, dat de Grondwet en de internationale norm een analoge bescherming bieden, dat die bescherming relevant is voor de oplossing van het geschil en dat de kwestie van die bescherming hem regelmatig is voorgelegd, van meet af aan de verwijzing naar het Grondwettelijk Hof positief moeten overwegen.

Dit is van belang om de convergentie te verwezenlijken tussen de hoge rechtsinstellingen. Het Grondwettelijk Hof moet de kans krijgen om mee te helpen bij die convergentie. De argumenten geput uit de noodzaak om spoedig te beslissen zijn niet determinerend. Vooreerst telt de prejudiciële procedure in beginsel mee voor de redelijke termijn; naast dat nogal formeel argument geldt ook dat de eis van de redelijke termijn kunnen wijken voor de eisen van een goede rechtsbedeling. ${ }^{\text {IOo }}$ Een goede rechtsbedeling kan bij samenloop in bepaalde gevallen eisen dat de zaak eerst verwezen wordt naar het Grondwettelijk Hof. Dit beantwoordt ook aan het verlangen van de nationale wetgever.

Die principiële redenen eerst aan het Grondwettelijk Hof een vraag te stellen moeten uiteraard genuanceerd worden. Die verplichting is bij samenloop niet automatisch. Als de wet (of het decreet) volgens het Hof van Cassatie klaarblijkelijk het verdrag schendt zal de wet buiten toepassing gelaten worden en wordt hiermede de facto of de jure het geschil beëindigd. Als de wet volgens het Hof van Cassatie het verdrag niet schendt, blijft dus het probleem bestaan van de verzoenbaarheid van de

99. Het is m.i. volledig kunstmatig na te gaan welke bepaling het meest waarborgen biedt, de internationale norm of de Grondwet. In de reële wereld zijn die beschermingen in feite gelijklopend omdat de nationale norm verdragsconform wordt uitgelegd en daarenboven doet de vraag welke norm het meest waarborgen biedt, de vraag rijzen wie dit mag bepalen (Grondwettelijk Hof of Hof van Cassatie). Het antwoord op die laatste vraag zal quasi volledig worden beïnvloed door de politieke keuze voor de ene of de andere instelling.

Ioo. EHRM, Ernst e.a. t. België, I5 juli 2003; Coeme e.a. t. België, 22 juni 2000. 
wet met de Grondwet en zou het Hof van Cassatie dus moeten verwijzen. Ook hier gelden een aantal uitzonderingen.

Die uitzonderingen kunnen te wijten zijn aan een foutief procesgedrag van de eiser in cassatie (bijv. zijn middelen geput uit het conflict Grondwet-wet zijn om een of andere reden niet ontvankelijk) ofwel kunnen zij te wijten zijn aan het feit dat de wet zelf in een dergelijk geval de verwijzing uitsluit ofwel nog is een verwijzing overbodig omdat het Grondwettelijk Hof reeds over dat conflict heeft geoordeeld.

Een actief gebruik van de eisen van een eerlijk proces, gepaard met een intelligente en wat creatieve lezing van de wetsbepalingen in hun onderlinge samenhang, heeft de toepassing van de regels van de wet van 6 januari I989 die de prejudiciële verwijzing beheersen naar het Grondwettelijk Hof, vereenvoudigd. Het eindresultaat is wellicht bevredigend omdat elk jaar het Hof van Cassatie zaken doorstuurt naar het Grondwettelijk Hof en dit laatste, vooral de laatste jaren, vermijdt vaststaande rechtspraak van de rechterlijke macht overboord te gooien.

\section{$7 \quad$ Het parket}

4I. De inbreng van het parket kleurt ook de taak van het Hof van Cassatie. Waar in andere rechtsinstanties het parket volledig los staat van de zetel, is dit minder waar in het Hof van Cassatie en was dit zeker niet het geval tot in I992, jaar waarop het EHRM het Hof van Cassatie verplichtte te beraadslagen zonder aanwezigheid van het parket. ${ }^{\text {IOI }}$ Van amicus curiae evolueerde het statuut van het parket naar dat van een eigenlijk parket. ${ }^{102}$ Hiermede kwam er een ongevraagde beperking aan een vorm van partenariaat tussen het Hof en zijn parket dat berustte op een eeuwenoude traditie. $^{\text {IO3 }}$

Die evolutie houdt niet in dat de hoofdtaak van het parket in zijn hoedanigheid van 'amicus curiae' adviezen te geven volledig verdwenen is. Ondanks de jurisprudentiele evolutie en de evolutie van de wetgeving die hierna zal worden besproken, maakt die taak nog steeds de kern uit van de activiteit van het parket bij het Hof van Cassatie. Die taak hangt immers nauw samen met de wijze waarop de rechtspleging verloopt en dat is niet fundamenteel gewijzigd.

De rechtspleging verloopt in hoofdzaak schriftelijk en zowel de leden van het Hof als van het parket kunnen hiervan kennis nemen. Bij de redactie van het concept van arrest neemt de rapporteur het voortouw. Hij doet opzoekingen en schrijft het voorontwerp. Wanneer het voorontwerp af is wordt het doorgestuurd na visum van de afdelingsvoorzitter naar de procureur-generaal bij het Hof van Cassatie die op dat ogenblik ook een advocaat-generaal belast met het geven van een advies. In civiele

Ior. Dit gebeurde pas in 1996 in civiele zaken. Zie ook, hoofdstuk II van Jaarverslag 2001 van het Hof van Cassatie - Het openbaar ministerie in de procedure voor het Hof van Cassatie en de nieuwe proceduremodaliteiten voor het Hof na de hervorming van I4 november 2000, te raadplegen op www.cass.be.

I02. De basisarresten van het EHRM zijn Borgers van 30 oktober I99I, Reinhart en Slimane Kaïd van 3I maart I998, Kress van 7 juni 200 I.

I03. Zie hierover 'Le parquet général de la Cour de cassation 'réformé' par la jurisprudence de la Cour européenne des droits de l'homme: mythe ou réalité?', Le Dalloz 2003, nr. 22. 
zaken ontstaat in die fase een zeer vruchtbare dialoog tussen het lid van het parket en de verslaggever. Zodra die dialoog af is, wordt de zaak in handen genomen door de voorzitter van de kamer die een hoorzitting bepaalt en ook een intens schriftelijk beraad organiseert waarbij het parket niet betrokken wordt. Met andere woorden, het openbaar ministerie wordt betrokken in voorbereidende activiteiten maar zodra anderen dan de rapporteur en de advocaat-generaal betrokken zijn, wordt de advocaat-generaal niet meer op de hoogte gehouden van de verdere evolutie van het dossier.

Het EHRM omschrijft de taak van het openbaar ministerie als volgt: 'L'avocat général n'est pas membre de la formation de jugement. Il a pour mission de veiller à ce que la loi soit correctement appliquée lorsqu'elle est claire, et correctement interprété lorsqu'elle est ambiguë. Il conseille les juges quant à la solution à adopter dans chaque espèce et, avec l'autorité que lui confèrent ses fonctions, peut influencer leur décision dans un sens, soit favorable, soit contraire à la thèse des demandeurs. ${ }^{\text {IO4 }}$

Maar ook al erkent het EHRM dat het openbaar ministerie bij het opperste gerechtshof een specifieke taak uitoefent, toch wenst het EHRM de rol van de advocaat-generaal anders in te vullen dan bestaande structuren het oplegden. Volgens het EHRM impliceert het recht op tegenspraak 'en principe, la faculté pour les parties à un procès, pénal ou civil, de prendre connaissance de toute pièce ou observation présentée au juge, même par un magistrat indépendant, en vue d'influencer sa décision'. ${ }^{105}$

Formeel belet de bestaande rechtspraak van het EHRM nog niet volledig een dialoog tussen de rapporteur en het lid van het parket dat het dossier behandelt. Die dialoog is nog steeds een belangrijke fase in de wording van het dossier. ${ }^{\text {Io6 }}$

42. Het blijft een juridisch delicate oefening omdat de partijen niet betrokken zijn bij die dialoog (die dus vooral belangrijk is in het eerste denkwerk over de zaak). Openbaarheid geven aan die dialoog betekent meteen die dialoog formaliseren en betekent ook een belangrijk tijdverlies dat het Hof zich niet kan permitteren. Moesten de justitiabelen of de advocaten aandringen op een dergelijke formalisering zouden de gevolgen vermoedelijk vrij drastisch zijn. De splitsing tussen openbaar ministerie en zetel zou onmiddellijk tot in haar laatste consequenties worden doorgevoerd... en de rapporteur zou ongetwijfeld nog meer de steun moeten missen van het parket. Dit kan niet de bedoeling zijn.

Het is opvallend dat in het Hof van Justitie van de Europese Gemeenschappen de advocaat-generaal ook present is in de eerste fase van het onderzoek van de zaak. Voor het Hof van Cassatie van België is dat niet veel anders.

43. De procureur generaal bij het Hof van Cassatie heeft, naast de leiding van het parket, ook een aantal specifieke opdrachten en bevoegdheden die illustreren hoe

I04. EHRM 3I maart I998, Reinhardt, nr. I05.

I05. EHRM, 20 februari I996, Lobo Machado, nr. 3 I.

Io6. Dit is anders in het nieuwe Franse systeem waarin de noot van de verslaggever niet wordt medegedeeld aan de advocaat-generaal die aldus autonoom werkt. 
belangrijk zijn taak was in het verleden en die nu anders worden ingevuld in de nieuwe ontwikkelingen van het Hof.

De procureur-generaal kan een cassatieberoep instellen in het belang van de wet. Die rechtsfiguur bestaat nagenoeg in alle landen en België vormt hierop geen uitzondering. Artikel ro89 van het Gerechtelijk Wetboek bepaalt: 'de beslissingen in laatste aanleg die strijdig zijn met de wetten of met de procesvormen en waartegen geen enkele partij in voorziening is gekomen binnen de wettelijke termijn, worden door de procureur-generaal ambtshalve aangebracht bij het Hof van Cassatie'. Die bevoegdheid is een waar monopolie voor de procureur-generaal en is niet aangetast door de huidige evolutie.

De procureur-generaal heeft ook een aantal bevoegdheden om nietigheidsvorderingen in te stellen op grond van machtsoverschrijding (artikelen 6o9 en 6ro van het Gerechtelijk Wetboek). ${ }^{\text {I07 }}$ Die monopoliepositie is afgezwakt geworden door de wetgeving (zie bijv. sub artikel 502 van het Gerechtelijk Wetboek) dat aan de voorzitter van de nationale ordes een dergelijke bevoegdheid toekent) en door de rechtspraak (een dergelijke monopoliepositie zou kunnen strijdig zijn met het gelijkheidsbeginsel of het recht op een eerlijk proces).

44. Een opvallende bepaling laat aan het Hof van Cassatie toe om ambtshalve de niet-ontvankelijkheid van een cassatieberoep (dus niet van een middel) op te werpen (artikel 1097, derde lid, van het Gerechtelijk Wetboek). De wet geeft hetzelfde recht aan het openbaar ministerie (artikel I097, eerste lid, van het Gerechtelijk Wetboek).

Wat vreemd is, is wat de praktijk hiervan gemaakt heeft. In nagenoeg alle gevallen waarin het cassatieberoep niet ontvankelijk lijkt, redigeert de rapporteur een concept van niet-ontvankelijkheid. De procureur-generaal werpt dan, in het geval een dergelijk middel niet is opgeworpen door de verweerder, een middel op van niet-ontvankelijkheid in een brief gericht aan de advocaten (en met een gerechtsbrief aan de partijen die geen advocaat hebben).

Het komt af en toe voor dat het openbaar ministerie het niet eens is met de rapporteur of met de afdelingsvoorzitter over de niet-ontvankelijkheid. In dit geval is het Hof gedwongen 'de zaak te verdagen' om de niet-ontvankelijkheid te laten onderzoeken. Er is geen formele heropening van het debat (want er is geen eigenlijk debat op het Hof van Cassatie) maar wel een gewone verdaging en een inlichting gegeven aan de partijen door de griffier.

45. In het verleden was een gouden regel dat het openbaar ministerie ook de contactpersoon was met de andere machten wat de neutraliteit van het Hof ten goede zou komen. Die strategie is sinds jaren verlaten onder de druk van de politieke wereld en de procureur-generaal is niet meer de enige gesprekspartner van de overheid: beide korpschefs zijn even actief.

Het beeld dat nu bestaat, neigt meer naar een model van autonomie van de ene en de andere. Beide hebben ook een disciplinaire bevoegdheid over bepaalde leden van

I07. Over de draagwijdte en bedoeling van die bepalingen zie F. Dumon, commentaar in Com. Ger. sub de artikelen Io88-ıogi. 
HUN zuil (zie de artikelen 398 en 399 van het Gerechtelijk Wetboek): de procureurgeneraal over de leden van het openbaar ministerie, de eerste voorzitter en de eerste kamer van het Hof over de leden van de zittende magistratuur. Dit is een verdere evolutie naar een distanciëring van beide.

46. De taken van het openbaar ministerie zijn dus thans ter discussie. De verplichting om in alle zaken een conclusie te nemen zou wellicht beter getemperd worden, om aan het parket de mogelijkheid te bieden alleen een conclusie te nemen in zaken die significant zijn voor de rechtsevolutie en de eenheid van het recht en die het parket van cassatie zelf uitkiest. Thans concludeert het openbaar ministerie grondig in alle zaken.

Reeds in het Hof van Justitie is het mogelijk dat een zaak zonder conclusie van de advocaat-generaal wordt berecht. Artikel 20 van het Statuut van het Hof van Justitie $^{\mathrm{I08}}$ biedt die mogelijkheid wanneer in die zaak geen nieuwe rechtsvraag aan de orde is. Het Hof maakt vrij veel gebruik van deze mogelijkheid. Bij ongeveer $33 \%$ van de in 2006 gewezen arresten is geen conclusie genomen (tegenover $35 \%$ in 2005). ${ }^{\text {I09 }}$ In tegenstelling tot het Hof van Justitie beschikt het Gerecht niet over permanente advocaten-generaal. Deze taak kan aldaar echter bij wijze van uitzondering aan een rechter worden opgedragen.

De vraag of het openbaar ministerie bij het Hof van Cassatie deel uitmaakt van het parket in de ruime zin van het woord heeft in andere landen de aandacht getrokken. In België is dit maar in beperkte mate het geval. De procureur-generaal is formeel niet de hiërarchische overste van de leden van de parketten generaal van de hoven van beroep maar heeft wel een disciplinaire bevoegdheid ten opzichte van die leden. Hij leunt weliswaar aan bij het Hof maar moet ook ageren op injunctie van de Minister van Justitie in bepaalde omstandigheden om zaken te onderwerpen aan het Hof.

In de praktijk is hij verwijderd van het beleid van het gewone parket in die zin dat de procureurs-generaal bij de hoven van beroep een college vormen voorgezeten door de Minister van Justitie en waarvan de procureur-generaal bij het Hof van Cassatie geen deel uitmaakt.

Het beeld is dus niet volledig duidelijk.

\section{$8 \quad$ Wetenschappelijke ondersteuning}

47. Een Hof van Cassatie kan alleen maar zijn taak vervullen met een sterke ondersteuning op juridisch en materieel vlak. De kern van de juridische ondersteuning zijn de referendarissen bij het Hof van Cassatie, ${ }^{\text {IIO }}$ die thans nagenoeg uitsluitend werken voor de leden van de zetel.

I08. Artikel 20 van het Statuut bepaalt: 'Wanneer het Hof van oordeel is dat in de zaak geen nieuwe rechtsvraag aan de orde is, kan het Hof, de advocaat-generaal gehoord, beslissen dat de zaak zonder conclusie van de advocaat-generaal zal worden berecht.'

Io9. Jaarverslag 2006 van het Hof van Justitie, 3 , te raadplegen op http://curia.europa.eu.

IIo. De wet van 6 mei 1997 strekkende tot de bespoediging van de procedure voor het Hof van Cassatie heeft het ambt van referendaris bij het Hof van Cassatie ingesteld. 
Het kader der referendarissen bij het Hof bedraagt dertig leden, maar de Minister mag bepalen welk het voorlopig maximum is. Dit is thans gesteld op I5, voor 30 raadsheren en I3 advocaten-generaal. Het aantal van I5 laat duidelijk te wensen.

Het statuut van de referendarissen bij het Hof van Cassatie makt het voorwerp uit van verschillende bepalingen van het Gerechtelijk Wetboek. Zij hebben, naar het voorbeeld van de referendarissen bij de andere hoogste rechtscolleges van het land (het Grondwettelijk Hof en de Raad van State), bepaalde rechten en plichten gemeen met de magistraten, ${ }^{\text {III }}$ zonder zelf magistraat te zijn stricto sensu. Zo genieten zij voorrang van rechtsmacht ${ }^{112}$ en worden zij bezoldigd overeenkomstig de weddebarema's van de magistraten. ${ }^{\mathrm{II} 3}$ Anderzijds gelden voor hen ook de onverenigbaarheden inzake cumulatie van ambten ${ }^{\mathrm{II} 4}$ en deze inzake bloed- en aanverwantschap die gelden voor alle magistraten. Inzake afwezigheid en verlof, zijn de referendarissen, net zoals de magistraten, onderworpen aan de bepalingen van de artikelen 33I, 332 en 333 van het Gerechtelijk Wetboek.

Het voorwerp en de aard van de specifieke opdracht toegewezen aan de referendarissen bij het Hof van Cassatie, verbindt hen met de uitoefening van de rechtsprekende functie. Hun taak - te vergelijken met die van de referendarissen bij het Hof van Justitie en het Grondwettelijk Hof - bestaat er immers hoofdzakelijk in bijstand te verlenen aan de magistraten bij het onderzoek van de cassatieberoepen. Aldus redigeren zij voorontwerpen van arresten of ontwerpen van conclusies van het openbaar ministerie en verrichten ze studies die bij het beraad worden gebruikt.

In de praktijk wordt op de bijstand van een referendaris gerekend in de nietroutine, complexere zaken, bijvoorbeeld in zaken waar zowel de heersende rechtsleer als rechtspraak zeer uiteenlopend is en een grondige studie noodzakelijk is. De vorm waarin de dialoog tussen de referendaris en de rapporteur wordt gevoerd hangt af van kamer tot kamer. Die dialoog is cruciaal voor de efficiëntie van die samenwerking.

Normaliter worden de referendarissen bij het Hof niet toegelaten tot het beraad. Het Hof van Cassatie heeft echter in een stafvergadering beslist dat voor bepaalde zaken waarop de aanwezigheid van de referendaris op het beraad een plus punt zou zijn, hij daartoe door de voorzitter van de kamer kon worden uitgenodigd.

In het verleden zijn in politieke kringen pogingen ondernomen om de referendarissen te onttrekken aan de rechterlijke orde en hen te onderwerpen aan een statuut dat niet meer door de wet is bepaald (zoals op dit ogenblik het geval is met het Gerechtelijk Wetboek), maar door middel van een koninklijk besluit. Die voorstellen doen afbreuk aan de nauwe band van de referendaris bij het Hof van Cassatie met de leden van het Hof en zijn tot nu toe met succes bestreden.

III. Zie ook, T. Erniquin, 'Les référendaires attachés aux juridictions supérieures', J.T. 2003, 7I7.

II2. Artikelen 479 en 483 van het Wetboek van Strafvordering.

II3. Artikel 365bis van het Gerechtelijk Wetboek.

II4. Artikelen 292 e.v. en 30 I t.e.m. 304 van het Gerechtelijk Wetboek. 
De referendarissen bij het Hof van Cassatie worden gerekruteerd door middel van een vergelijkend examen, bestaande uit drie proeven dat door het Hof zelf is ingericht. ${ }^{\text {II } 5}$ De kandidaten moeten minimum 25 jaar oud zijn om eraan te kunnen deelnemen. De inrichting van het examen door het Hof zelf heeft ertoe geleid dat wetenschappelijk gemotiveerde en bekwame kandidaten konden geselecteerd worden door het Hof.

De wens bestaat in het Hof en daarbuiten om aan de referendarissen de quasiautomatische toegang te verlenen tot het statuut van magistraat, na enkele jaren dienst wat de magistratuur te goede zou komen. Dit zou het Hof ook toelaten goede referendarissen een aantal jaren in dienst te houden zonder hen te zien weggaan naar universiteit of balie.

48. Naast de referendarissen kunnen een aantal magistraten (een tiental) ook deeltijds gedetacheerd worden naar het Hof om daar wetenschappelijke arbeid te doen en tegelijkertijd ervaring te krijgen in cassatiewerk. Die meestal ervaren magistraten werken hoofdzakelijk voor het openbaar ministerie.

\section{$9 \quad$ Ondersteuning door de verplichte procesvertegenwoordiging}

\section{I De verplichte vertegenwoordiging in... $40 \%$ van de gevallen}

49. In civiele zaken is, behoudens uitzonderingen, de bijstand door een advocaat bij het Hof van Cassatie verplichtend. Hierop bestaan enkele uitzonderingen: in fiscale zaken kan een gewone advocaat optreden of zelfs een fiscaal ambtenaar (maar niet een partij in persoon), het pleiten kan ook gedaan worden door een gewone advocaat (maar dus niet het inleiden van een zaak). In de zaken die geen eigenlijke cassatieberoepen zijn, is de bijstand van een advocaat evenmin verplicht.

Zonder die verplichte vertegenwoordiging door een advocaat die behoort tot een aparte balie, zou het Hof een nog veel sterkere bijstand nodig hebben. Zoals het nu is, is de redactie van de cassatieberoepen en memories van antwoord over het algemeen bevredigend naar vorm en inhoud. Het hoort niet bij de deontologie van de advocaat bij het Hof van Cassatie te pogen het Hof in een val te lokken of overmatig lange cassatieberoepen of zelfs middelen die patent geen slaagkans hebben, op te stellen. De organisatie van een aparte balie heeft zeer gunstige vruchten afgeworpen.

Uit de statistieken opgemaakt elk jaar door het Hof in verband met de slaagkans van de cassatieberoepen kan worden afgeleid dat de slaagkans spectaculair stijgt of daalt naargelang er al dan niet een advocaat bij het Hof is opgetreden. ${ }^{\text {II6 }}$

II5. Deze recrutering is fundamenteel verschillend van die van de referendarissen bij de hoven van beroep en rechtbanken. Deze moeten slagen voor twee proeven, georganiseerd door het Selectiebureau voor de federale overheid (Selor) en hun stageperiode bedraagt een jaar (Zie B.S. 2I november 2002 en I juni 2007).

II6. jaarverslag 2006 van het Hof leert ons bijv. dat in 2006, $43 \%$ van de civiele zaken succesvol waren, tegen $15 \%$ strafzaken, waar de bijstand van een advocaat bij het Hof van Cassatie niet vereist is (p. 253). 


\subsection{Cassatieadvocaten: een filter?}

50. Zijn cassatie-advocaten een rem op de toevoer van zaken? In zekere mate wel. De gespecialiseerde advocaten kunnen goed de slaagkansen afwegen en hun correspondenten overtuigen geen cassatieberoep in te stellen.

Is dit een financiële rem? Die vraag verdient een genuanceerd antwoord. Een advocaat bij het Hof van Cassatie vraagt uiteraard een ereloon maar de praktijk wijst uit dat de advocaten meestal, gelet op hun monopoliepositie, veel minder vragen dan wat zij aan hun gewoon cliënteel aanrekenen. ${ }^{\text {II7 }}$

Daarenboven heeft de rechtsbijstand voor het Hof (met ook vormen van gedeeltelijke rechtsbijstand) zich zeer sterk ontwikkeld zodat thans bij de $20 \%$ van de zaken ingeleid worden met rechtsbijstand. De financiële drempel is geen echte drempel meer, vooral nu het aantal verzekerden voor rechtsbijstand enorm gestegen is.

Corresponderend bestaat er ook weinig vraag om de kosten van advocaat bij het Hof van Cassatie te laten aan de Staat.

II7. Taxering van het ereloon van de advocaat wordt door het Hof niet gedaan. 